The participation of universities in technology development: do creation and use coincide? An empirical investigation on the level of national innovation systems

Reinhilde Veugelers, Julie Callaert, Xiaoyan Song and Bart Van Looy

DEPARTMENT OF MANAGERIAL ECONOMICS, STRATEGY AND INNOVATION (MSI) 


\title{
The Participation of Universities in Technology Development: Do Creation and Use coincide? An Empirical Investigation on the Level of National Innovation Systems
}

\author{
Reinhilde Veugelers ${ }^{\circ *}$, Julie Callaert ${ }^{\circ}$, Xiaoyan Song ${ }^{\circ}$, Bart Van Looy ${ }^{\# \#}$ \\ ${ }^{\circ}$ Department of Management, Strategy and Innovation - Research Division INCENTIM ; \\ ECOOM, Catholic University of Leuven, Leuven, Belgium \\ * Senior Fellow at Bruegel, Brussels, Belgium

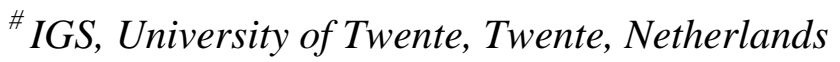

Corresponding author: $\quad$ Prof. Dr. Reinhilde Veugelers

K.U.Leuven, FBE-MSI

Naamsestraat 69 - Bus 3535

3000 Leuven

Belgium

Phone: +32 16326908

Fax: +32 16326732

Email: Reinhilde.Veugelers@econ.kuleuven.be

Paper prepared for the special issue in Economics of Innovation and New Technology on Academic Entrepreneurship and Economic Competitiveness;

April 2011; revised October 2011

The authors acknowledge financial support from the Research Fund of the KULeuven (OT/07/011), FWO (G.0523.08), PAI (09/06), and EU-FP SciFiGlow, as well as comments from the participants in the San Sebastian Workshop. 


\begin{abstract}
Relying on patent information, we map the presence and impact of universities in technological landscapes across several major countries and fields. The creation of academic technology is examined by analysing patents applied for by universities. The 'use' of academically owned technologies is assessed through citations from industrially owned patents towards university patents. Considering simultaneously the creation and use of academic technology allows to assess to what extent the creation of academic technology coincides with its subsequent 'use' including the role played by geographic proximity in this respect. Our findings reveal a dominance of American universities in terms of creating academic technology, particularly in terms of highly cited academic patents. US firms dominate in terms of citing academic technologies. They limit themselves not to American universities. . European and Asian countries vary considerably in terms of creation and use of academic technology and display a more outspoken 'home bias'.
\end{abstract}

Keywords: entrepreneurial universities, academic patents, patent citations

JEL codes: 030, 034 


\section{Introduction}

As the concept of 'innovation systems’ has gained widespread acceptance since the mid-1980s, the role of and the interplay between different types of innovation actors is nowadays recognized as crucial for understanding the dynamics behind innovative performance, growth and competitiveness of nations (e.g. Freeman, 1987, 1994; Adams, 1990; Lundvall, 1992; Nelson, 1993; Mowery and Nelson, 1999; Baumol, 2002).

The pivotal role of universities in innovation systems can be found in the literature on the 'Triple Helix' concept, which rose to prominence in the second half of the 1990s (Leydesdorff and Etzkowitz, 1998; Etzkowitz and Leydesdorff, 1997). In these models, universities are considered as relevant and distinctive actors in innovation systems, contributing to the innovative potential of societies. This holds particularly for their role in basic research, which is characterized by high levels of technological and market uncertainty and considerable lead times often spanning decades. Private investors tend to refrain from basic research, leaving universities and public research institutes uniquely positioned to produce science-based knowledge upon which the development of new products, processes and services can build.

In the literature on the role of universities in innovation systems, it is increasingly being stressed that for universities to effectively contribute to the capacity of an innovation system, they should not only create ideas that can be commercialized, but they also have to be involved in the process of transferring research ideas towards commercial success. The notion of ‘entrepreneurial universities’ (Branscomb, Kodama \& Florida, 1999; Etzkowitz, Webster \& Healy, 1998) refers to universities becoming more active in the transfer of research results, through patent and license activities, spin-off activities, collaboration projects with the industry, and greater involvement in economic and social development in general. Some speak of a 
'second academic revolution' that took place in the 1990s, adding entrepreneurial objectives as a third component to the mission of the university (Etzkowitz, Webster and Healy, 1998).

In many countries, policy measures have been introduced in an attempt to improve the contribution of universities to national innovation potential (Cohen and Noll, 1994). These include support schemes for cooperation between business and academia and measures that regulate intellectual property rights, such as the Bayh-Dole Act and the Stevenson-Wydler Act in the U.S. These regulations - which gave the universities the right to obtain intellectual property rights (IPR) from federally funded research (Nelson 2001, Mowery et al, 2001, 2004) effectively boosted the adoption and the further development of IPR-related procedures and policies at universities (Branscomb et al. 1999; Clark, 1998; Van Looy et al., 2003). Several countries, also in Europe, have adopted similar support schemes and regulatory frameworks (OECD, 2003).

From the side of demand for science-based knowledge, firms - in employing more open innovation strategies (Chesbourgh, 2003) - rely increasingly on public science as an external source, allowing rapid and privileged access to new knowledge, especially in the life sciences (Cockburn \& Henderson 2000; Zucker et al. 1998; Klevorick et al, 1995). Firms that rely on scientific research findings are expected to develop a deeper understanding of the technological landscapes in which they search for new inventions; allowing them to better anticipate, evaluate and translate the outcomes of their technology activities (Rosenberg, 1990; Fleming and Sorenson, 2004). Empirical evidence from surveys of corporate and academic researchers (Mansfield, 1995 \& 1998; Cohen et al, 2002, Veugelers \& Cassiman 2004) indeed indicate the importance of university research for industrial innovation activities. 
All these developments have implied a more direct and larger-scale involvement of universities than ever before both in technology creation and knowledge transfer (Geuna \& Muscio 2009). Empirical studies have attempted to evidence these trends, using various proxies to quantify the activities of universities in innovation. Shane (2002) investigated licensing of university generated innovations. Other papers have examined academic spin-off activities (Shane 2002, Zucker et al. 1998; Audretsch \& Stephan 1996), or the role of university science parks (Siegel et al. (2003)). University-industry collaborative research has received attention in studies by (a.o.) Hall, Link \& Scott (2000); Cockburn \& Henderson (2000); Mohnen \& Hoareau (2003); Belderbos et al. (2004). Others have examined the use of public science by firms as indicated by their patents referring to scientific publications (Narin et al, 1997; Verbeek et al., 2002; Van Looy et al., 2003, 2006) or citing academic patents (Henderson et al., 1998; Mowery et al., 2001).

Most of these empirical studies confirm an intensification of the entrepreneurial role of universities over time. These developments are especially outspoken within rapidly growing technologies that are close to the 'science base' (Kodama and Branscomb, 1999; Mowery et al., 2001), such as biotechnology, IT, microelectronics, and nanotechnology. At the same time, there is a strong suggestion of heterogeneity: some institutions and/or some countries appear much more active in academic technology creation and science-technology linkage than others (Debackere \& Veugelers, 2005; Van Looy et al., 2011). This means that although the relevance of new university-created technology for today's innovation systems is widely recognized, the actual translation of scientific knowledge into usable technological developments - and the role enacted by universities - is not straightforward and varies greatly between countries. 
Unfortunately, insights into the basic mechanisms of creation and use of academic technology and the impact of science on the innovation performance of nations is still fraught with a lack of analysis and evidence. What is particularly lacking are quantitative indicators that are able to cover a large set of institutes, countries and technologies over time. Our contribution tries to fill this gap.

Using patent data, we map the presence and impact of universities in technological landscapes across a number of major countries (national innovation systems) and technologies. We first look at where academic technology is developed, measured by patents with university applicants: which countries, which technological fields and which institutions are most active in creating 'academic' technology? Whereas this provides an insight into the 'supply'- side of academic technology, it can be argued that the creation of economic wealth ultimately will depend on the extent to which this technology is being 'used' by firms. Therefore, we provide complementary data which shed light on the 'use' of university-originated technologies within corporate technology development efforts. This is measured by backward citations from industrially owned patents towards university patents. Mapping simultaneously the creation and use of academic technology by country allows to assess whether and to what extent the creation of academic technology coincides with its subsequent 'use' by industry. In addition, an analysis of cross-country flows between creating and using countries permits to confirm the importance of geographic proximity as evidenced in the micro-econometric works of Jaffe et al. (1993) and Audretsch \& Stephan (1996) at the country level.

In the analysis, we are particularly interested in examining the position of Europe relative to the US in academic technology creation and use. Is there a European academic 'technology' deficit relative to the US? Or parallel with the European paradox on academic science, an 
academic entrepreneurship paradox with European academic technology being used less by European firms and perhaps more frequently observed within non-European, industrial technological, activities?

The paper is structured as follows. In the following section, the data are presented. Next, we highlight the main observations with respect to the creation of academic technology, followed by the findings pertaining to the use of academic technology by firms. Combining both sets of observations allows developing a new perspective on the role of universities - across countries in terms of technology development and their use. We conclude with some tentative policy implications.

\section{Data}

\subsection{Measuring the Participation of Universities in Technology Creation}

We measure the participation of universities in technology creation through patents filed by universities. Patents have since long been recognized as reliable data sources for indicators of innovation and technical change (e.g. Griliches, 1990; Hall et al., 2001). University patenting data deliver straightforward indicators of academic technological activity. They have the advantage of wide coverage across countries, technologies and time. As we aim to assess the participation of academic institutions in technology creation across countries and technological domains, the broad coverage patent data provides is crucial.

The data used in this analysis pertain to all patent applications filed at the European Patent Office (EPO) with at least one university applicant. We opted for EPO rather than USPTO 
data, as information on applications is available in much more detail in the EPO data files ${ }^{1}$. With applications being more numerous than granted patents, a more comprehensive picture is created by examining applications. The allocation of the applicant to a sector (universities, firms, individuals,...) is based on the methodology developed by Van Looy et al. (2006) and further refined by Du Plessis et al. (2009). We look at the application years between 1980 and 2000. The cut-off at 2000 is to allow for a citation window of 10 years to assess patterns of 'use'.

Using the registered volumes of patent applications by universities implies an underestimation of the actual inventive and technological activity taking place at universities. This is due to several reasons. First, not all technologically relevant research results are patentable. Second, not all results that are patentable are disclosed or filed as a patent. Although this may to some extent be true also for firm patents, the underestimation may be more outspoken for universities, where the threshold to patent is still higher than in industry. Third, university patents are identified as such if the applicant (or at least one of them) is a university. This implies that patents with academic inventors, but no university applicant, are not included. The entailed underestimation can be quite considerable. Estimations from previous studies suggest that over $20 \%$ of US patents by academic inventor are assigned to firms (Fabrizio \& DiMinin, 2008; Thursby et al., 2009). Similar estimations for Europe reveal even higher figures (from 50\% to over $80 \%$ ). The latter is due to institutional differences and different national legislations regarding intellectual property rights arising from university research (Lissoni et al., 2008). As the referred studies illustrate, mapping all patents of academic inventors is a painstaking process of matching university personnel lists with inventor names, as patent data contain no information on inventor affiliation. Within the framework of the large-scale

\footnotetext{
${ }^{1}$ The USPTO only started to release application information from 2000 onwards and only in a systematic manner for applications that are also filed elsewhere (including PCT applications)
} 
assessment across countries aimed for in this contribution, such an effort is not feasible. Furthermore, for some countries, a large portion of academic researchers (and inventors) is at the same time affiliated to large public research institutes; e.g. CNRS in France, Fraunhofer Gesellschaft in Germany, CNR in Italy,... Patents from these inventors may be assigned to these public research institutes and therefore not be visible in the statistics on university patenting. Moreover, although most countries have since the beginning of the 2000's abolished the professor's privilege rule whereby individual professors - rather than their universities - are entitled to the property rights, differences remain in the timing and the course of legislative changes (see Van Looy et al., 2011). Hence, the underestimation of technological activities at universities that is entailed by measuring university patents, will be higher for some countries than for other countries.

In terms of national innovation systems, global coverage is assured by including all OECD member countries as well as China and Taiwan. For assessing the domain specific nature of universities' technological activity, we rely on the technology classification developed by ISIFraunhofer (Schmoch, 2008). Full counts have been applied for patent applications involving applicants from multiple countries and/or situated within multiple technology domains.

\subsection{Assessing the Use of Academic Technology: Citations from Industry-owned Patents}

Besides assessing the creation of university patents, we also analyze the 'use' of these patents. Whether and where university technology creation will be relevant for subsequent technology development is perhaps an even more critical issue for society than the question on whether and where academic patents are created. Academic patents often represent early stage technology development, where the potential use is still unclear or uncertain (e.g. Jensen \& Thursby, 2004). 
One way of assessing the impact of academic patents is to consider whether they are licensed or not (e.g. Link \& Scott, 2002). Such an approach however not only implies a rather restrictive operationalisation of valorization (with knowledge not only being used or referenced, but also being paid for), but would require comprehensive data on licensing activities covering different countries and technology fields which are currently not available._An alternative approach towards measuring technology flows - which we adopt within this paper -implies the analysis of citations between patents.

We measure the impact or the 'use' of academic technology by considering backward citations from corporate patents to university patents. Patent citations reveal to what extent future technology development efforts are related to the knowledge reflected in the source document (Jaffe et al., 1993; Jaffe \& Trajtenberg, 2002). Although citations in patents do not necessarily represent direct connections between the citing (corporate) actor and the cited (academic) actor, they do reflect relatedness between the technological developments at the corporate side and the academic developments that preceded them. A higher intensity of citations between corporate and university patents are hence, at the firm side, indicative of a more intense reliance on university technology when developing technology.

No restrictions are placed on citing patent authority (USPTO, EPO, national patent offices...), or citing applicant country, but we do restrict the analyses to citing patents that are owned by companies. This allows a clear focus on citation flows from academic technology towards the industrial texture. Overall, for university patents citations from company patents represent $76 \%$ of all citations received by university patents. We consider a 10 -year citation window. For university patents, this period captures $80 \%$ of the citations received (see Figure 1). 
Two different indicators are used to capture the extent to which university patents are referred to by company patents: whether or not they receive citations by corporate patents and upon receiving at least one citation, the number of citations received.

Forward citations - received by university patents from corporate patents - are highly skewed (see Figure 2). 84\% of university patents receive no corporate citations. This high number of non-cited university patents illustrates the importance of looking beyond the generation of university patents to assess their "use".

***INSERT FIGURE 2***

Conditional on being cited, a university patent receives on average 5,25 citations from company patents, but with a high standard deviation (7). Overall, about $4 \%$ of cited university patents are "highly cited", i.e. receiving more than 19 forward company citations.

\section{The Presence and Impact of Universities in the Technology Landscape}

\subsection{University Patenting by Country and Field}

The trend of a more prominent role of universities in technology development and the rise of the entrepreneurial university, as discussed supra, is indeed at least partly reflected in growing university patent shares (see Table I). Over the last three decades, the university share in patenting activity has almost quadrupled from less than $1 \%$ in the eighties, over $2 \%$ in the 
nineties to over 3\% by 2007 (see also Van Looy, 2009).

\section{***INSERT TABLE I***}

At the same time, the extent of university involvement in technology development varies strongly across technology fields and countries. Technology field effects are related to the science intensity of technologies. Country differences are at least partly related to the role of universities in the national institutional textures, and to differences in national legislations with respect to ownership of intellectual property rights originating from publicly funded research (Van Looy et al., 2011). An ANCOVA analysis (cf. Appendix table A.I) confirms that country and technology-fields are significant factors explaining a considerable share of the variance in university patenting activity. In the following sections, we shed further light on the contribution of universities in technological landscapes, where we distinguish between technology fields and countries.

\section{Technology field effects}

As can be seen in figure 3, almost $40 \%$ of all university are situated within Pharmaceuticals. Using the Herfindahl index as a measure of concentration ${ }^{2}$ reveals that the concentration for university patents in technology fields $(\mathrm{HI}=0,18)$ is three times higher than for patents overall $(\mathrm{HI}=0,06)$. This suggests that academic technology is much more concentrated within a limited number of fields.

\footnotetext{
${ }^{2}$ Herfindahl is a commonly used measure for concentration. It is the weighted sum of the share of each technology in the total number of university patents, with the weights being the share. The Herfindahl ratio varies between 0 (maximal dispersion) and 1 (perfect concentration).
} 
***INSERT FIGURE 3***

The most 'science-intensive’ technologies are Pharmaceuticals, Measurement and Medical Equipment; as shown in table II. These fields score highest in terms of share of patents with universities as applicants. They also have the highest score on 'relative weight of university patenting'. The latter is calculated as the share of university patents in technology field i, relative to the share of university patents in all technologies.

\section{UnivPat technology i / UnivPat all technologies}

AllPats technology i / AllPats all technologies

Fields with an index higher than 1 can be considered as ‘intensive' or 'specialized' in university patenting, their share in university patenting being higher than their share of universities in patenting overall.

***INSERT TABLE II***

\section{Country Effects}

The ANCOVA results (cf .Appendix table A.I) confirm that besides technology field effects, country effects are highly significant in explaining the participation of universities in technology creation. And as these country effects hold even after including technology and countrytechnology interactions, the prominence of country effects in university patenting go beyond a mere specialization of countries in science intensive technologies. 
Figure 4 shows that $68 \%$ of all university patents are held by the United States ${ }^{3}$.

European countries (EU-15) take a much lower share: 21.15\%. Within Europe, the UK is the largest player, and number 2 in the world. The world top 5 is further completed by Canada, Belgium and Australia.

The Herfindahl index, as a measure of concentration, reveals that the dominance of the US in university technology creation is even more outspoken than its dominance in technology creation overall: the concentration for university patents is substantially higher $(\mathrm{HI}=0,48)$ than for patents overall $(\mathrm{HI}=0,17)$.

\section{***INSERT FIGURE 4***}

Table III shows university patenting as a share of total patent activity within each country for the major countries in the sample (see Appendix table A.II for a list of all countries). The 'relative weight of university patenting' is again calculated as the share of university patents in country i, relative to the share of university patents in all countries.

$\frac{\text { UnivPat }_{\text {country } i} \text { / UnivPat all countries }}{\text { AllPats } \text { country } i_{\text {/ AllPats all countries }}}$

A country that has a value larger than 1 is 'intensive', or, 'specialized' in university patenting, i.e. the country has a higher weight in total university patenting than its weight in all

\footnotetext{
${ }^{3}$ Note that the figures concern EPO patents, so this prevalence holds in spite of a potential home bias for European countries. The dominance of the US in generating university patents remains statistically significant and large even when correcting for technology field effects, as a regression analysis with fixed field effects and a US dummy reveals. Similarly, the results for an EU dummy and a Japan dummy confirm a significantly negative coefficient.
} 
patenting, or, the country has an above average share of its patenting activity taking place at universities.

***INSERT TABLE III***

The countries with the highest specialization in university technology development are Australia, Canada, Belgium, US, UK. Also China, Ireland and Spain have a high value in terms of specialization in university patenting due to a combination of modest technology activity with universities present in technology development.

The EU15 overall does not 'specialize' in university patenting. This is due to the fact that many of its major patenting countries are only to a very limited extent active in university patenting: most notably Germany, France, the Netherlands and Italy as well as Scandinavian countries. For a number of these countries, this is a consequence of the regulations on intellectual ownership within academia. Several European countries have only recently (after 2000) abandoned the 'professor's privilege' rule in favour of 'Bayh-Dole' oriented regulations (e.g. Germany and Denmark) (see Van Looy, 2009). In addition, in some countries - notably Germany, France and Italy - a considerable part of publicly funded research is conducted at Public Research Organisations, like CNRS, CNR, Fraunhofer. Consecutive technology development activities undertaken by these PRO's are not included in the data analysed here, where the focus is on universities exclusively.

When moving to the level of individual institutes, the distribution of academic patenting becomes even more skewed, being concentrated in a limited number of institutes. The worldwide top 25 players in university patenting, although they represent only 2,6\% of all patenting universities, hold almost $40 \%$ of all university patents. US universities figure prominently (22 
institutes among the 25), with the University of California, coming first, followed by MIT, the University of Texas and Stanford. Canada, Belgium and the UK each have one institute in the top 25 (respectively British Columbia, IMEC and Oxford University).

\subsection{Use or impact of University Patenting by Country and Field}

In this section, several citation-based indicators are presented to distinguish academic technology activities by their impact. Looking at the extent to which university created technologies are actually being used is important, as many university patents end up left "un-used" (cf. infra). The impact or 'use' of university patents is assessed by looking at the citations received by these patents in subsequent corporate patents. The probability of being cited is considered; and, for the cited patents, the average number of citations received (average impact). At the citing side, only company patents are considered, whereas the cited patent is university-owned. For comparison, we include similar indicators for cited patents owned by companies.

An ANCOVA analysis (cf. Appendix table A.III) confirms that a considerable share of the observed variance in terms of the share of cited university patents and their average impact is related to differences in terms of country and technology field. In the following sections, we report the share of cited university patents and their average impact on the technological landscape, distinguishing between technology fields and countries.

\section{Technology Field Effects}

Compared to company patents, a much lower share of university patents is cited (see table IV). But in terms of average impact of the cited patents (i.e. the amount of citations received per cited patent), university patents are in the same range as company patents. University patents in Pharmaceuticals - the technology field that is most intensely populated by university patents - 
have the lowest propensity to receive any citations. In all technologies, university patents are much less likely to receive citations as compared to corporate patents, but the divergence between the two is highest in Pharmaceuticals. On the other hand, conditional on being cited, university patents in this field receive the highest number of corporate citations. The average impact factor of university owned patents within this field, as in several other fields, is even higher than the average impact factor of cited corporate patents.

***INSERT TABLE IV***

\section{Country Effects}

Table V shows the citation-based statistics for a selection of countries which hold at least 100 university patents. (see Appendix Table A.IV for a table with all countries). The US is again dominant, receiving $66.8 \%$ of all corporate citations to university patents. This share of being cited is slightly below the US share in the creation of university patents (68\%). The US also has a relatively low percentage of its university patents being cited (14\%, compared to an EU15 average of 28\%). Nevertheless, conditional on being cited, US university patents display the highest impact factor, with an average of more than 5 citations received per cited university patent. This impact factor is higher than the impact factor of US corporate patents. The same holds for Belgium, Germany and Italy, where university patents - although less frequently cited - appear to have higher impact than corporate patents, conditional upon being cited. ${ }^{4}$

\footnotetext{
${ }^{4}$ These results are not driven by technology field and time effects, i.c. a specialization of the US in science based technologies like Pharmaceuticals. Including a US dummy next to technology field and time effects in regression analysis, results in the US dummy to be negative, but insignificant for share of cited patents, but significantly positive for impact of the cited university patents.
} 
The EU-15, on average, holds $23 \%$ of all citations received from company patents to university patents. EU-15 university patents are more likely than their US counterparts to be cited by corporate patents. But conditional on being cited, their average impact is much lower (3.74) $)^{5}$. Within the EU-15, Belgium's university patents hold a top position in terms of corporate citations received. Not only do Belgian university patents have a higher probability of receiving citations by corporate patents, they also have the highest impact in Europe. The Belgian university patenting success story largely benefits from the presence of IMEC, an interuniversity centre for micro-electronics. Spain also scores high in terms of share of university patents being cited, but their impact is modest. Japan's university patents have the highest probability of being cited by company patents (together with Spain), but - conditional on being cited - their average impact is not exceptionally high and lower than the impact of their company owned patents ${ }^{6}$.

***INSERT TABLE $V^{* * *}$

Table VI provides a summary of the major indicators on creation and impact of university patents for the US, the EU15 and Japan. The table clearly reveals different profiles for each of these world regions. In terms of quantity, the US is clearly dominant: it produces a large volume of university patents, leaving the EU-15 at a large distance. The quantity of university patents in Japan is modest. However, when we turn our attention to citation indicators, only a limited

\footnotetext{
${ }^{5}$ These results are not driven by technology field and time effects. Including a EU dummy next to technology field and time effects in regression analysis, results in the EU dummy to be significantly positive for share of cited university patents, but significantly negative for impact of the cited university patents.

${ }^{6}$ These results are not driven by technology field and time effects. Including a Japan- dummy next to technology field and time effects in regression analysis, results in the JAP dummy to be significantly positive for share of cited patents, but insignificant for impact of the cited patents.
} 
number of US academic patents end up being cited by the corporate sector (14\%). This citation rate is much higher for university patents from the EU-15 (28\%) and particularly for Japan (48\%). Hence these countries have fewer but more frequently cited university patents. However, when looking at the average number of citations received, conditional on being cited, the US again takes a strong lead over the EU15 and Japan, with their university patents having a higher impact factor on average. This is reminiscent of US university patents having a higher likelihood to become a top cited patent.

\section{***INSERT TABLE VI***}

These results suggest that, in terms of profiles, the US model of university technology creation seems to be one of experimentation on a large scale. The US generates a large volume of university patents, from which only a minor portion end up being 'used' in subsequent corporate technology creation. This large volume at the same time allows for a more fertile ground for university patents to bloom into highly cited patents, at least for a few. This experimentation process is especially characteristic for the Biotech (Pharmaceutical) field (cf supra). Europe displays a different profile: universities are less active in generating patents, but bring out ideas that have a relatively high probability to become 'used'. However, with less experimentation going on, they are less likely to result in 'high impact'. Japan, be it on a much smaller scale, resembles the European mode in as far as university patenting is concerned.

\section{The Use of University Technology: Who cites University Patents?}

As knowledge spillovers are an important driver of firm productivity (Jaffe, 1986) and economic growth (Romer, 1990), it becomes highly relevant to identify the use by the corporate sector of 
university patents across countries and technology fields. In this section, we dive deeper into who is citing university patents. We map the receiving end of technology flows from universities to the corporate sector.

We consider as citing patents all EPO company patents with application years between 1990 and 2009. Backward citations to university patents are considered, taking into account a 10 year (backwards) citation time lag. We calculate two indicators for measuring the extent to which companies refer to academic technology in their own patent applications. First, the share of corporate patents that cite university patents is calculated (as a portion of all company patents). Second, for corporate patents that cite university patents, we consider the citation intensity; i.e. the average number of backward citations to university patents per citing company patent.

An ANCOVA analysis (see Appendix table A.V) shows that there are significant country and field differences in the extent to which the industrial texture 'uses' academic technology. Country and field effects hold when controlling for time, and for the national technology specialization profiles that are captured by the interaction effect. We therefore report the corporate use of academic technology by technology field and country.

\section{Technology Field Effects}

At the technology side, differences stem from technology characteristics - and more specifically the science intensity - of the citing technologies. Technologies in science-intensive fields are not only characterized by higher shares of university patenting; their corporate patents are at the same time likely to have more intense citation links to academic technology. This is confirmed in table VII, where especially Pharmaceuticals, but also Measurement, and Medical Equipment show a high corporate absorption rate of university technologies. 
***INSERT TABLE VII***

Country Effects

National differences in the citation behaviour of corporate patents to university technology are one indication of the extent to which national innovation systems incorporate academic knowledge; or the extent to which national systems are able to further develop academic - often early-stage technologies (cf. Jensen \& Thursby, 2001) . Several interdependent country-specific factors may affect the extent to which academic technological know-how is used in the development of corporate technical inventions, such as the industrial structure (firm size, presence of large R\&D-intensive global corporations), the quality and relevance of academic research, the presence of university/industry relationships, as well as national policies and programs concerning private $R \& D$ and the commercialization of public research (Tijssen (2002)).

Table VIII provides an overview of country differences in the corporate use of university technology. The highest share of company patents that cite university patents can be found in Australia and China. Although these high shares are partially due to lower absolute figures in the denominator, the observation of these countries' high university citing behaviour is not a trivial one. We also see a large corporate citation share towards university technology in Denmark, US, Ireland and the UK. It suggests that the corporate environment in these countries 'absorb' more frequently technologies originating out of universities.

***INSERT TABLE VIII***

Table IX summarizes for the three regions, US, EU15 and Japan, the major indicators on 
corporate use of university technology. Not only is the US dominant in terms of creation of university technology, the US corporate sector is also more active in relying on university technology. The EU corporate sector is significantly less active in “using” university patenting, an observation which holds when controlling for technology fields and time trends.

\section{Mapping Countries on Creation and Use of University Technology}

Figure 5 plots countries by their creation and use of university technology. Countries can show a larger discrepancy between the academic 'supply' and the corporate demand side of academic technologies. In order to evaluate such discrepancy, it is useful to distinguish 4 quadrants, representing high versus low creation shares and high versus low corporate citing shares of university technology. The demarcation lines between the quadrants represent the world average shares of creation and use of university technology.

\section{***INSERT FIGURE 5***}

Countries in the upper right quadrant are those where both the share of university technology that is developed (academic supply side) and the citing share of university technology (corporate demand side) are above average. The US combines high levels of creation with high levels of use of academic patents. Albeit on a smaller absolute scale, the positions of Australia and China are noteworthy. Even though they may be smaller players in technology development overall (cf. table III), their high levels of creation and use of academic technology indicate dynamic innovation systems that seek to exploit knowledge through close sciencetechnology interactions. It remains to be seen whether these countries 'use' their local created 
academic technology or whether they source externally (cross-border) academic technology. This will be considered in section 6 .

Countries in the lower right quadrant are relatively prolific in creating university technology, but at the same time lag behind in corporate use. These countries are at risk of creating academic technology, but failing to use it in subsequent corporate technology development.

The upper left quadrant represents countries whose own creation of academic technology is limited, but their corporate sector is an intense user of university technology. They probably rely on 'imported' academic technology. This quadrant hosts mostly Nordic countries and - be it to a much lesser extent - the UK. The next section on cross-country citation flows will provide an insight on where these countries source their academic technology.

Countries in the lower left quadrant have a low national supply of university technology, and a corporate texture which sources relatively little knowledge from academic technologies. Looking at the countries in this quadrant reveals a heterogeneity that suggests several reasons. As already discussed earlier, some countries have a minor national supply of university technology because of specific national legislations and institutional textures at the supply side. For these countries, at the same time, a lower national supply of university technology also implies less citations from the corporate to the university sector. To what extent cross-border corporate citations to university patents may or may not compensate for a lack of indigenous university patents, will be made clear in the next section on cross-country citation flows. What is important to note at this point is that a lower manifestation of university-based technology does not necessarily coincide with poor technological performance on a national level. This becomes clear when the position in the lower left quadrant is related with the position of these countries 
on overall national technological performance (in terms of national patent volumes, see table III). Especially the presence in this quadrant of technological 'blockbusters' like Germany, Japan, France but also Italy and Finland are a case in point: in spite of low creation and absorption shares of academic technology, these countries are leading players in terms of technology development worldwide. Corporate sectors in these countries may specialize in technologies which are less 'science' intensive.

\section{Cross-Country Flows of Academic Technology}

Further diagnosis of countries' positions in the different quadrants benefits from an overview on cross-country flows of academic technology: which countries of corporate "use" cite which countries of academic “creation”? In table X, we provide a closer look at cross-country citations flows from citing corporate patents to cited academic patents. The matrix maps the intensity of flows between citing and cited countries. The cell values represent relative intensities of citation linkages between the citing countries (rows) and the cited countries (columns), with grey cells indicating within-country citation flows. The following formula was used to calculate these relative intensities: $\quad \mathrm{CCC}_{\mathrm{ij}}=$

$$
\begin{aligned}
& \text { citations of corporate citing country i to academic cited country j } \\
& \qquad / \text { total citations of corporate citing country i }
\end{aligned}
$$

citations to corporate cited country $\mathrm{j} /$ total corporate citations

A value higher than 1 represents a link between corporate citing country and university cited country which is overrepresented. Of particular interest are the (grey) values for same citing and cited country, as these capture the home-advantage in corporate citations to university 
patents. Table X only provides information for the most important citing and cited countries (for the full matrix, see Appendix table A.VI).

All within country links (grey) have values (sometimes considerably) higher than 1 . This confirms that proximity matters for tighter links between creation and use of academic patents. These results are consistent with micro-level findings on the importance of geographic proximity for closer industry-science links (e.g. Jaffe et al.,1993; Audretsch \& Stephan, 1996).

A home bias effect is present but less outspoken for the US, which nevertheless has the highest volume of corporate patents citing university patents (cf. table VIII). This shows that, even though a sufficiently large domestic pool of academic technology is available, US companies also tend to intensively use international academic technology to complement their domestic sources. The home bias is also less outspoken for the UK, and for Japan and Germany: all large countries in terms of corporate patents citing university patents, but with the latter two small in terms of university patent development.

On the other end of the spectrum, the home-bias is exceptionally strong for China, Ireland and Spain, which is partly due to small numbers, both on the citing and the cited side. It is also particularly strong for Australia, Canada and France.

Looking beyond home-bias effects, other geographic proximity effects (citation flows to neighbouring countries) are not apparent. Besides a few exceptions (such as Spain citing France; and Germany citing France, Switzerland and Belgium), most neighbouring pairs do not display citation intensities higher than 1 ; nor do cells with values higher than 1 systemically represent neighbouring ties. Cross-country links between creation and use of academic patents appear to be more plausibly explained by technology field specializations than by geographic proximity. 
***INSERT TABLE $X^{* * *}$

Finally, when looking at the proportions of cited countries per citing country (see Appendix table A.VIII), US universities are always (for all citing countries) by far the largest recipient of corporate citations to university patents. Nevertheless, for most citing countries (excl. NO), the link with US academic patents is underrepresented (be it often close to 1). This reflects that for non-US corporations, compared to US corporations, it appears to be more difficult to link to US academic patents.

\section{Conclusion and Discussion}

The growing involvement of universities in technology creation and the rise of the entrepreneurial university model is a much discussed phenomenon in many countries. Unfortunately, insights into the basic mechanisms and impacts of universities on innovation performance of nations is still fraught with a lack of quantitative indicators that are able to cover a large set of institutes, countries and technologies over time. Our contribution tries to fill this gap. Using patent information, covering EPO applications for the period 1980-2000, we map the creation and use of universities in technological landscapes across technologies and countries over time. We look at where academic technology is developed, measured by patents with university applicants. In addition, we look at the 'use' of these university-originated technologies within corporate technology development efforts. This is measured by backward citations from industrially owned patents towards university patents.

In terms of the creation of academic technology, our findings not only reveal strong field effects with the presence of universities most outspoken in pharmaceuticals, measurement and 
medical instruments; considerable country effects become apparent as well. US universities account for the lion share of university owned patents (68\%) while the EU-15 accounts for $21 \%$ of all university owned patents. The heterogeneity present in Europe, both in terms of institutional texture as well as in terms of legislative framework conditions pertaining to the ownership of publicly funded research are part of the source for the observed country differences.

Also in terms of corporate "use" of university patents, as measured by citations by corporate patents to university patents, we find significant country differences, beyond technology field and time trends. European university patents receive slightly more citations from industrially owned patents - than can be expected from the mere presence of European universities within the technology landscape. This result does not support those who would argue that there is a European paradox with respect to entrepreneurial universities. Nevertheless, while European academic patents are more likely to receive citations (from industry) as compared to the US, the average number of citations - conditional upon being cited - is significantly and considerably higher for US university owned patents. This observation suggests that the technology patent portfolios of American universities are characterized by high volumes and higher levels of 'risk'. While this translates in fewer patents to become cited, it also results in more probability for 'highly' cited patents. To the extent that such highly cited patents are playing a pivotal role in terms of wealth creation, the US finds itself in an advantageous position.

Analysing which nationality of universities are being cited by corporate patents, confirms that such citation flows are to a large extent 'localized', with own national university patenting being cited most likely. At the same time, it can be noted that these 'localized' patterns are most strongly observed for European and Asian countries. The US displays a citation pattern of 
university patents by corporates which shows 'sourcing' of knowledge on a truly global scale. To the extent that such global sourcing is instrumental for wealth creation, the US displays the strongest profile.

Should Europe emulate the US model and increase the scale of its university technology creation and use? While this might imply that a larger proportion of university patents may not be cited, it could result in a more fertile ground in terms of experimentation resulting in more 'breakthrough' university technologies that will be extensively used in subsequent corporate technology development, first and foremost in the home country. Such a question can only be addressed if the full impact of this model on technological, innovative and economic performance is assessed, an endeavor that awaits further research.

Beyond relating our findings to economic impact, other issues require further investigation in order to frame evidence based policy suggestions. First, a more recent time period should be analyzed for university technology creation, as many European countries have changed their institutional setting on academic IP after 2000. This would however imply that a shorter window on "use” will be available. The role and nature of academic inventions which are not patented by universities, but by individual scientists or by other, corporate, applicants, or by public research organizations, need to be looked at, particularly to assess how much of the 'lower' performance of certain European countries is due to differences in IP regulations and/or institutional landscape. Also complementary information on the "use" of academic patents such as licensing, although difficult to obtain on a large cross-country and technology scale, merits further exploration. In this respect, the work of Link and Scott (2002) - focusing on licensing agreements between firms in the chemical industry - can be seen as a source of inspiration. In this study, citations of (potential) licensees towards licensor's patents turn out to be a significant 
predictor of license agreements. To the extent that a similar relationship would hold for companies citing academic patents, the involved universities would find themselves in an advantageous position to benefit economically from their technological activities.

With the data at hand, the analysis can be moved from a descriptive to a more analytical level, trying to unravel the factors explaining the country heterogeneity in university technology creation and use which the current contribution has demonstrated forcefully. What characteristics of the US innovation system explain its high scoring on the quality of its university technology creation and/or corporate technology use? For the policy discussion it would be particularly interesting to identify the significant factors that can be used as policy levers. Are the more horizontal framework conditions more critical, creating the conditions for delivering high quality academic research, smooth transfers between academic research and the corporate texture, and/or higher incentives from the corporate sector to capture academic technology? Or do more targeted policy instruments, like subsidies or IP regulations, aimed at stimulating industry-university collaboration, the commercialization of public research by universities and/or the adoption of university technology by firms, provide the background for the development of an innovation system with universities as pivotal actors.

\section{References}

- Adams, J. 1990. Fundamental stocks of knowledge and productivity growth. Journal of Political Economy 98, 673-702.

- Arrow K. 1962. Economic welfare and the allocation of resources for invention. In The Rate and Direction of Inventive Activity, ed. R. Nelson. Princeton University Press, NJ. 
- Audretsch, D. B. and P. E. Stephan. 1996. Company-scientist locational links: The case of biotechnology. The American Economic Review 86, No 3: 641-652.

- Baumol, W.J. 2002. The Free-Market Innovation Machine: Analyzing the Growth Miracle of Capitalism. Princeton University Press.

- Belderbos, R., M. Carree, B. Diederen, B. Lokshin and R. Veugelers. 2004. Heterogeneity in R\&D cooperation strategies. International Journal of Industrial Organization 22, No. 8-9: 1237-1263.

- Branscomb, L.M., Kodama, F., \& Florida, R. 1999. Industrializing Knowledge: University-Industry Linkages in Japan and the United States. London, MIT Press.

- Chesbrough, H. 2003. Open Innovation: The New Imperative for Creating and Profiting from New Technology. Harvard Business School Press.

- Clark, B.R. 1998. Creating Entrepreneurial Universities: Organizational Pathways of Transformation. Oxford, Elsevier Science for IAU Issues in Higher Education.

- Cockburn, I.M., \& Henderson, R.M. .2001. Publicly funded science and the productivity of the pharmaceutical industry. In Innovation Policy and the Economy, Volume 1, ed. A.B. Jaffe, J. Lerner \& S. Stern. MIT Press.

- Cohen, L.R., \& Noll, R.G. 1994. Privatising public research. Scientific American 271: 7277.

- Cohen W., Nelson R. and Walsh J., 2002. Links and impacts: The influence of public research on industrial R\&D. Management Science 48, No.1: 1-23

- Debackere, K., \& Veugelers, R. 2005. The role of academic technology transfer organizations in improving industry science links. Research Policy 34, No.3: 321-342.

- Du Plessis, M., Van Looy B., Song X. Magerman, T. (2009). Data Production Methods for Harmonized Patent Statistics: Patentee Sector Allocation. Eurostat Working Paper and Studies, Luxembourg.

- Etzkowitz, H., \& Leydesdorff, L. 1997. Introduction to special issue on science policy dimensions of the triple helix of university-industry-government relations. Science and Public Policy 24: 2-5.

- Etzkowitz, H., Webster, A. \& Healy, P. 1998. Capitalizing Knowledge: New Intersections of Industry and Academia. State University of New York Press. 
- Fabrizio, K. and A. DiMinin. 2008. Commercializing the Laboratory: Faculty Patenting and the Open Science Environment. Research Policy 37: 914-931.

- Fleming L. and Sörenson O., 2004. Science as a map in technological search. Strategic Management Journal 25: 909-928.

- Freeman, C. 1987. Technology and Economic Performance: Lessons from Japan. Pinter, London.

- Freeman, C. 1994. The economics of technical change: A critical survey article. Cambridge Journal of Economics 18, No.5: 463-514.

- Geuna, A., \& Muscio, A. 2009. The governance of university knowledge transfer: A critical review of the literature. Minerva 47, No. 1: 93-114.

- Griliches, Z. 1990. Patent statistics as economic indicators: A survey. Journal of Economic Literature 28: 1661-1707.

- Hall, B.H., Link, A.N., \& Scott, J.T. 2001. Barriers inhibiting industry from partnering with universities: Evidence from the advanced technology program. Journal of Technology Transfer 26, No. 1-2: 87.

- Hall, B. H., Link, A.N., \& Scott, J.T. 2003. Universities as research partners. Review of Economics \& Statistics 85, No. 2: 485-491.

- Henderson, R., Jaffe; A.B., \& Trajtenberg, M. 1998. Universities as a source of commercial technology: A detailed analysis of university patenting, 1965-1988. Review of Economics and Statistics 80, No. 1: 119-127.

- Henderson, R.M., Cockburn, I., 1996, Scale, scope and spillovers: the determinants of research productivity in drug discovery. RAND Journal of Economics 27, No. 1: 32-59.

- Hu, G.Z. \& Jaffe, A.B. 2003. Patent citations and international knowledge flow: The cases of Korea and Taiwan. International Journal of Industrial Organization 21, No. 6: 849-880.

- Jaffe, A.B. 1986. Technological opportunity and spillovers of R\&D: Evidence from firms' patents, profits and market value. American Economic Review LXXVI: 9841001.

- Jaffe, A.B., \& Trajtenberg, M. 1999. International Knowledge Flows: Evidence from Patent Citations. Economics of Innovation and New Technology 8: 105-136. 
- Jaffe, A.B., Trajtenberg, M., \& Henderson, R. 1993. Geographic localization of knowledge spillovers as evidenced by patent citations. The Quarterly Journal of Economics 108, No. 3: 577-598

- Jensen, R.A., \& Thursby, M.C. 2001. Proofs and prototypes for sale: The licensing of university inventions. The American Economic Review 91, No. 1: 240-259.

- Jensen, R.A., Thursby, J.G., \& Thursby, M.C. 2003. Disclosure and licensing of university inventions: The best we can do with the $\mathrm{S}^{* *} \mathrm{~T}$ we get to work with? International Journal of Industrial Organization 21, No. 9: 1271-1300.

- Klevorick A.K., Levin R., Nelson R. and Winter S., 1995. On the sources and significance of inter-industry differences in technological opportunities. Research Policy 24: 185-205.

- Kwanghui Lim, K. 2009. The many faces of absorptive capacity: Spillovers of copper interconnect technology for semiconductor chips. Industrial and Corporate Change 18, No. 6: 1249-1284.

- Leydesdorff, L., \& Etzkowitz, H. 1998. Triple helix of innovation: Introduction .Science and Public Policy 25: 358-364.

- Liebeskind, J.P., Oliver, A.M., Zucker, L., Brewer, M. 1996. Social networks, learning and flexibility: Sourcing scientific talent in new biotechnology firms. Organization Science 7, No. 4: 428-443.

- Lissoni, F; Llerena, P., McKelvey, M. \& Sanditov, B. 2008. Academic patenting in Europe: New evidence from the KEINS database. Research Evaluation 17, No. 2: 87102.

- Lundvall, B.-Å. 1992. National Systems of Innovation. Pinter, London.

- Mansfield E., 1995. Academic research underlying industrial innovations: sources, characteristics and financing. The Review of Economics and Statistics 77: 55-65.

- Mansfield E., 1998. Academic research and industrial innovation: An update of empirical findings. Research Policy 26: 773-776.

- Mohnen, P., \& Hoareau, C. 2003. What type of enterprise forges close links with universities and government labs? Evidence from CIS 2.L Managerial and Decision Economics 24, No. 3-2: 133-145. 
- Mowery, D.C., \& Nelson, R.R. 1999. Sources of Industrial Leadership. Cambridge University Press, Cambridge.

- Mowery, D.C., Nelson R.R., Sampat B.N., \& Ziedonis A. 2001. The growth of patenting and licensing by US universities: An assessment of the effects of the Bayh-Dole Act of 1980. Research Policy 30, No. 1: 99-119.

- Mowery, D.C., Nelson R.R., Sampat B.N., \& Ziedonis A. 2004. Ivory Tower and Industrial Innovation: University-Industry Technology Transfer before and after the Bayh-Dole Act. Stanford University Press.

- Narin, F., Hamilton, K.S., \& Olivastro, D. 1997. The increasing linkage between US technology and science. Research Policy 26: 317-330.

- Nelson, R.R. 1993. National Innovation Systems. Oxford University Press, New York.

- Nelson, R. 2001. Observations on the post-Bayh-Dole rise of patenting at American universities. Journal of Technology Transfer 26, No. 1-2: 13.

- OECD. 2003. Turning science into business. Patenting and licensing at public research organizations. OECD Publications, Paris.

- Romer, P. 1990. Endogenous technological change. Journal of Political Economy XCVIII: S71-S102.

- Rosenberg N. 1990. Why do firms do basic research (with their own money)? Research Policy 19, No. 2: 165-174.

- Schmoch, U. 2008. Concept of a technology classification for country comparisons. Final report to the world intellectual property organization, WIPO.

- Shane, S. 2002. Selling university technology: Patterns from MIT. Management Science 48, No. 1: 122-137.

- Siegel, D. S., Waldman, D.A., Atwater, L.E., \& Link, A.N. 2003. Commercial knowledge transfers from universities to firms: Improving the effectiveness of university-industry collaboration. Journal of High Technology Management Research 14, No. 1: 111-133.

- Tijssen, R.J.W. 2002. Science dependence of technologies: Evidence from inventors and their inventions. Research Policy 31, No. 4: 509-526.

- Thursby, J., Fuller, A.W., Thursby, M. 2009. US faculty patenting: Inside and outside the university. Research Policy 38, No. 1: 14-25. 
- Van Looy, B. 2009. The role of universities within innovation systems: An overview and assessment. Review of Business and Economics 1.

- Van Looy B., Magerman T. \& Debackere K. 2007. Developing technology in the vicinity of science: An examination of the relationship between science intensity (of patents) and technological productivity within the field of biotechnology. Scientometrics 70, No. 2: 441-458

- Van Looy, B., Debackere, K., Callaert, J., Tijssen, R., van Leeuwen, T. 2006. National scientific capabilities and technological performance: An exploration of emerging industrial relevant research domains. Scientometrics 66, No. 2: 295-310.

- Van Looy, B., Du Plessis, M., Callaert, J., Meyer, M., \& Debackere, K. 2011. The impact of legislative framework conditions on the technological performance of European Universities: An empirical assessment. Paper presented at the 13th ISSI Conference 2011, Durban, South-Africa.

- Van Looy, B., Du Plessis, M. \&Magerman, T. 2006. Data Production Methods for Harmonized Patent Indicators: Patentee sector allocation. Eurostat Working Paper and Studies, Luxembourg.

- Van Looy, B., Landoni, P., Callaert, J., van Pottelsberghe, B., Sapsalis, E., \& Debackere, K. 2011. Entrepreneurial effectiveness of European universities: An empirical assessment of antecedents and trade-offs. Research Policy 40, No. 4: 553-564.

- Van Looy, B., Debackere, K. and Andries, P. 2003a. Policies to stimulate regional innovation capabilities via university-industry collaboration. R\&D Management 33: 209229.

- Van Looy, B., Zimmermann, E., Veugelers, R., Mello, J., Verbeek, A., Debackere, K. 2003b. Do science-technology interactions pay off when developing technology? An exploratory investigation of 10 science-intensive technology domains. Scientometrics 57: 355-367.

- Verbeek, A., Debackere, K., Luwel, M., \& Andries, P. 2002. Linking science to technology: Using bibliographic references in patents to build linkage schemes. Scientometrics 54, No. 3, 399-420. 
- Veugelers, R. and Cassiman, B. 2005. R\&D Cooperation between Firms and Universities: Some empirical evidence from Belgian Manufacturing. International Journal of Industrial Organisation 23, No.5-6: 355-379.

- Zucker, L., Darby, M. 1995. Virtuous circles of productivity: star bioscientists and the institutional transformation of industry. NBER working paper \#5342.

- Zucker, L., Darby, M., \& Armstrong, J. 1998. Geographically localized knowledge: Spillovers or markets? Economic Inquiry 36, No. 1: 65-86. 
Figure 1. Number of forward citations received by university patents, per time lag (EPO, all years).

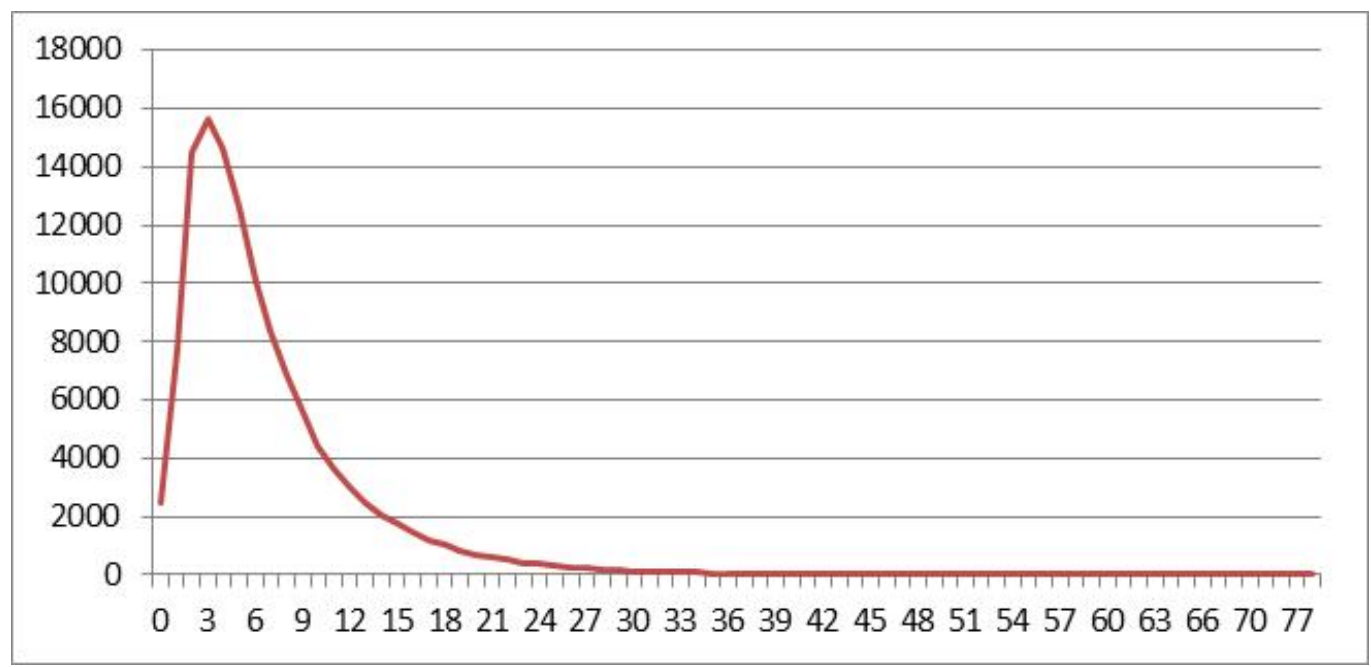

Figure 2. Frequency distribution of forward citations received by university patents (EPO, application years 1980-2000).

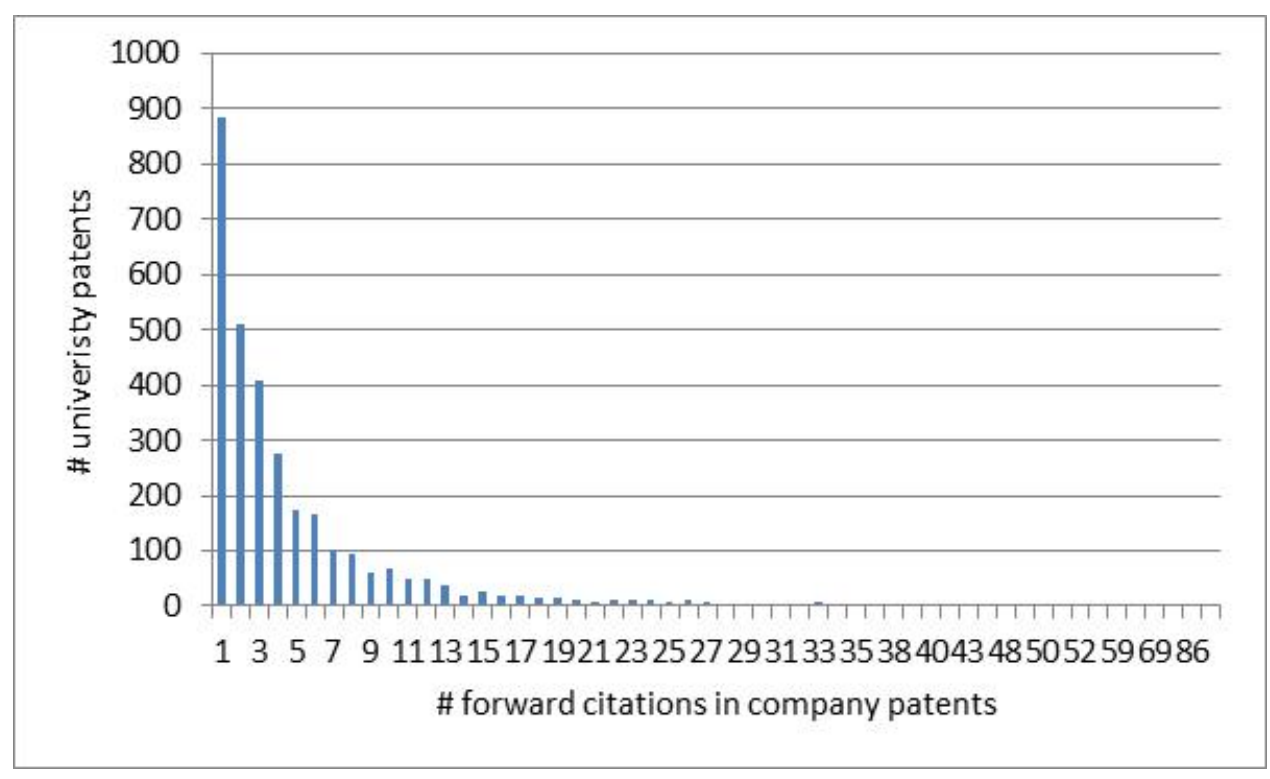


Figure 3. University patenting by technology field (EPO, application years 1980-2000).

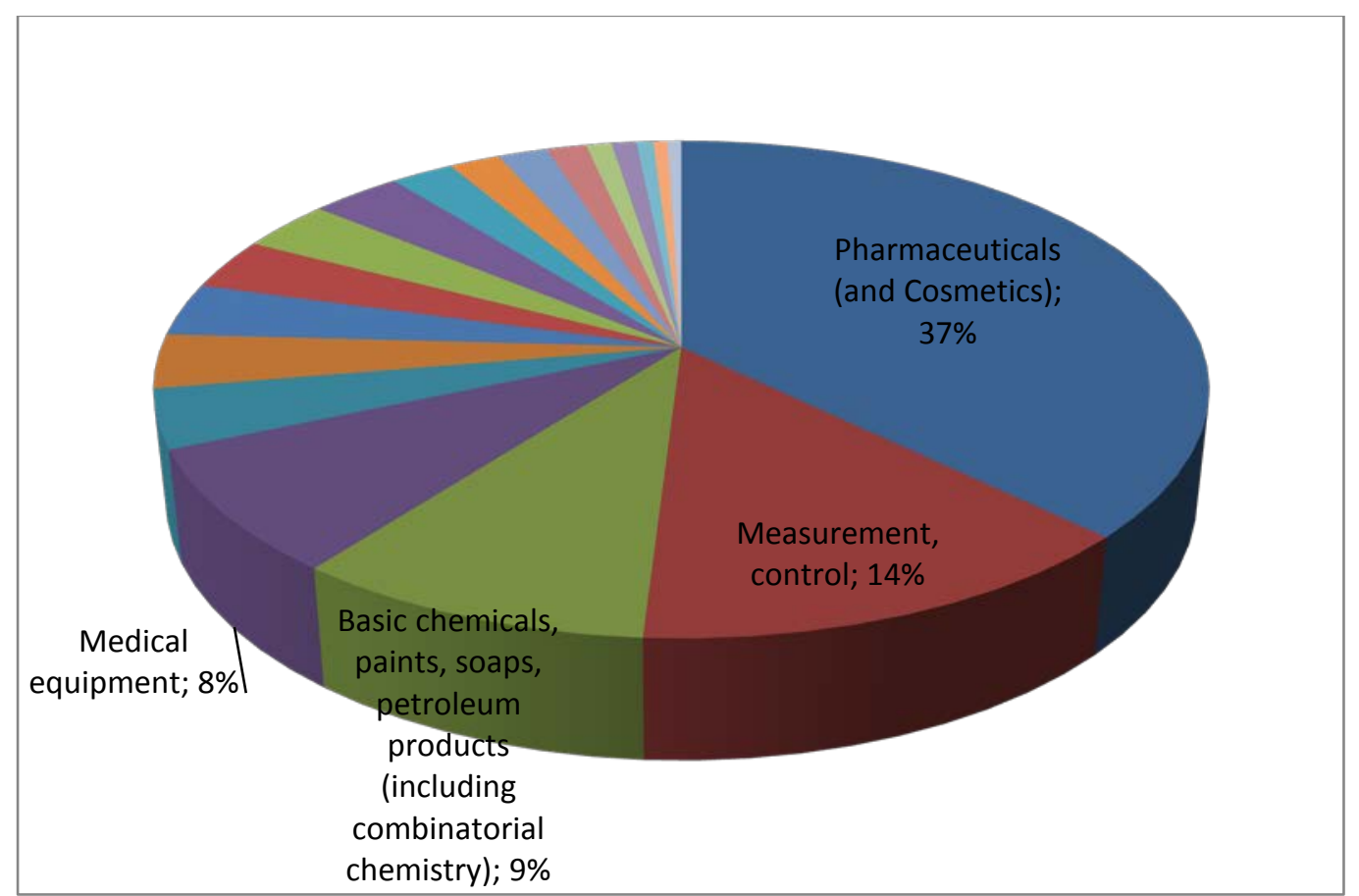

Figure 4. University patenting by country (EPO, application years 1980-2000).

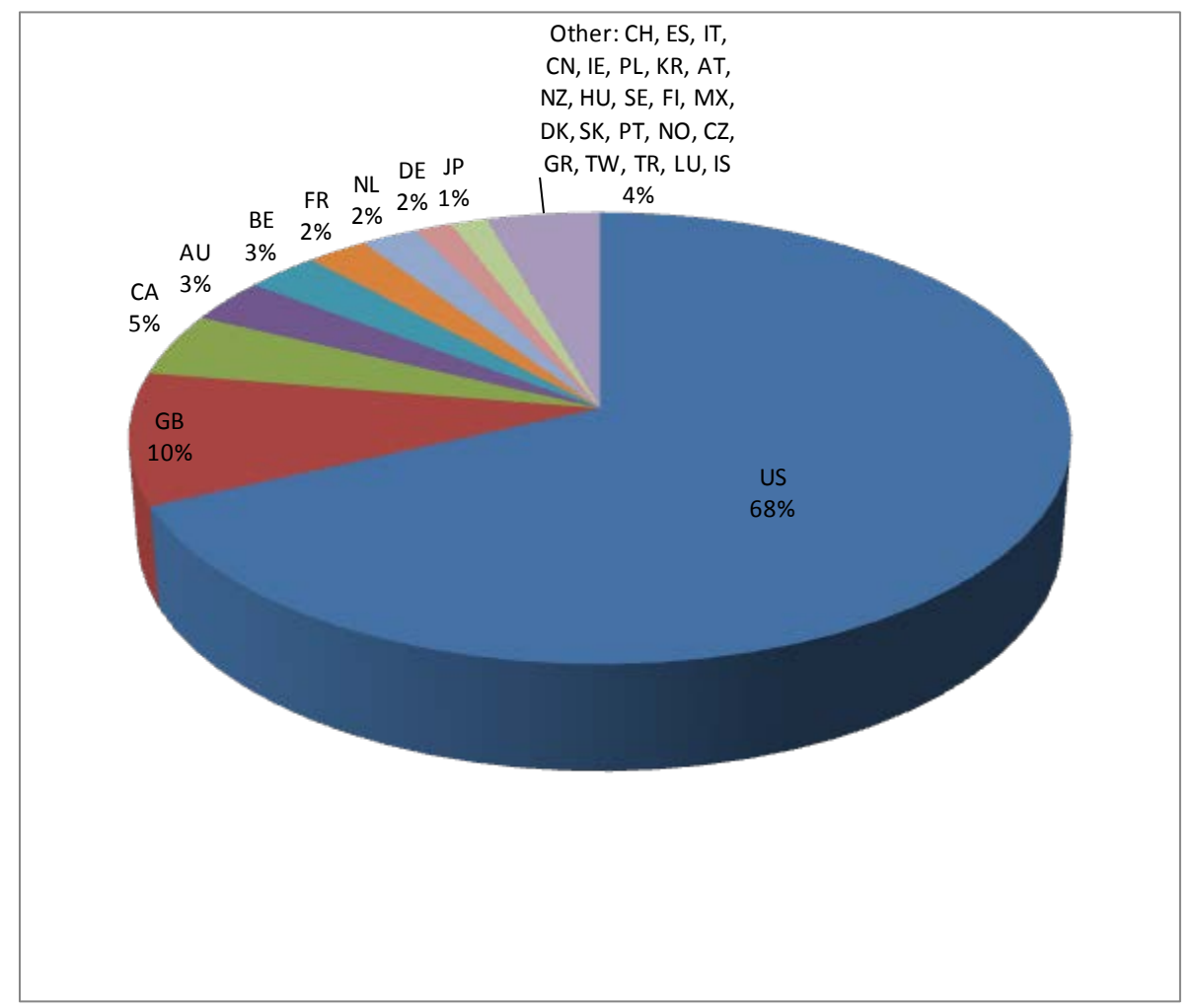


Figure 5. Creation (EPO application years 1980-2000) versus use (EPO application years 19902009) of university technology, by country.

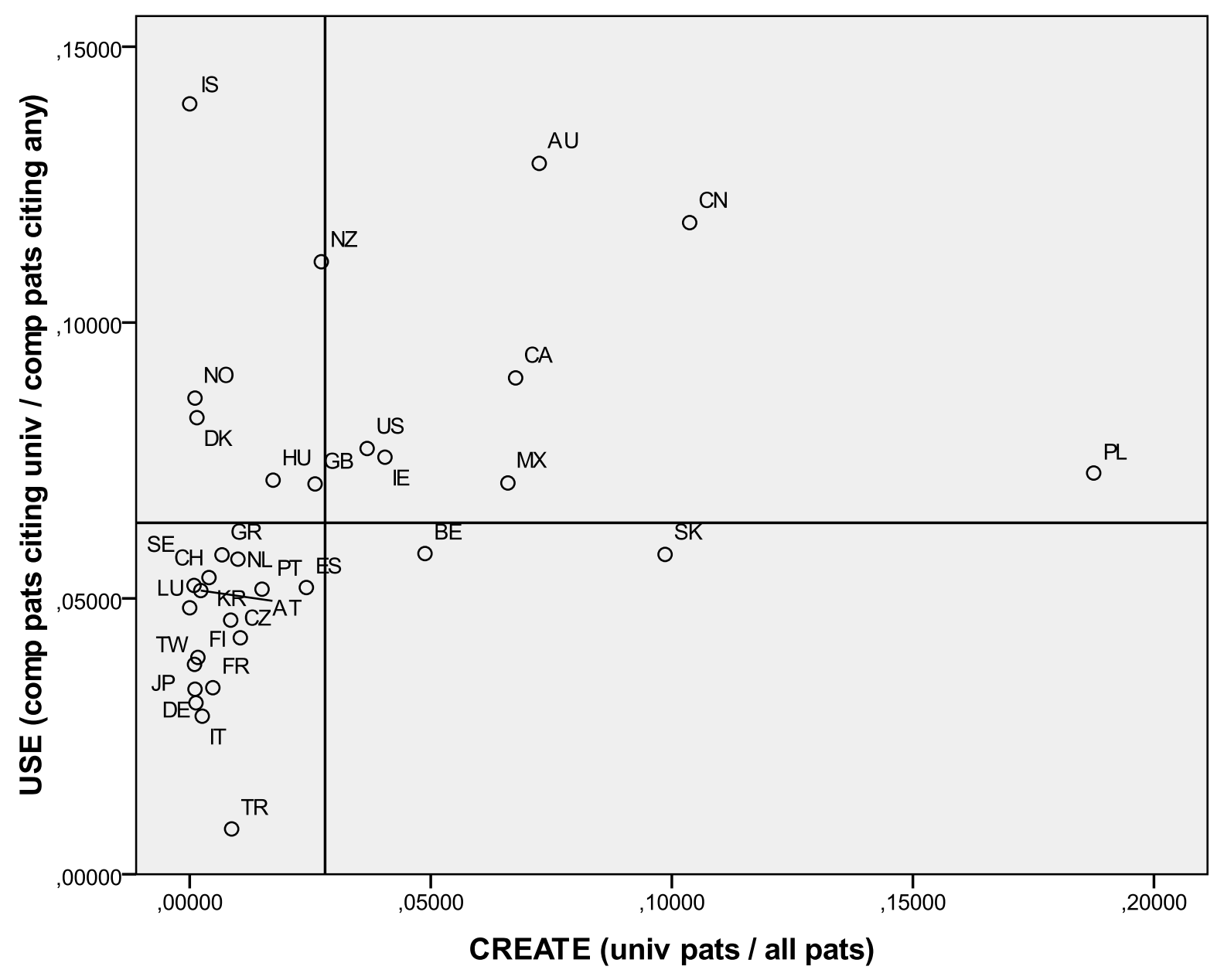


Table I. Trends in university participation in technology development (university assignees, EPO).

\begin{tabular}{|l|c|c|c|c|c|}
\hline Sector & $\mathbf{1 9 8 0 - 1 9 8 5}$ & $\mathbf{1 9 8 6}-\mathbf{1 9 9 0}$ & $\mathbf{1 9 9 1 - 1 9 9 5}$ & $\mathbf{1 9 9 6}-\mathbf{2 0 0 0}$ & $\mathbf{2 0 0 1}-\mathbf{2 0 0 7}$ \\
\hline Company & $84,90 \%$ & $87,04 \%$ & $88,55 \%$ & $88,42 \%$ & $89,02 \%$ \\
\hline Government / non-profit & $2,41 \%$ & $2,36 \%$ & $1,98 \%$ & $2,09 \%$ & $2,29 \%$ \\
\hline Hospital & $0,07 \%$ & $0,15 \%$ & $0,19 \%$ & $0,22 \%$ & $0,19 \%$ \\
\hline Individual person & $11,84 \%$ & $9,30 \%$ & $7,70 \%$ & $7,00 \%$ & $5,84 \%$ \\
\hline University & $0,79 \%$ & $1,16 \%$ & $1,57 \%$ & $2,28 \%$ & $2,66 \%$ \\
\hline & $100,00 \%$ & $100,00 \%$ & $100,00 \%$ & $100,00 \%$ & $100,00 \%$ \\
\hline
\end{tabular}

Table II. University patenting by technology field (EPO, application years 1980-2000).

\begin{tabular}{|c|c|c|c|c|}
\hline Technology & Patents & $\begin{array}{l}\text { University } \\
\text { patents }\end{array}$ & $\begin{array}{l}\text { \% university } \\
\text { patents }\end{array}$ & $\begin{array}{l}\text { Relative weight of } \\
\text { university } \\
\text { patenting }\end{array}$ \\
\hline Pharmaceuticals (and Cosmetics) & 147.107 & 11.191 & $7,61 \%$ & 4.41 \\
\hline Measurement, control & 102.723 & 4.137 & $4,03 \%$ & 2.34 \\
\hline $\begin{array}{l}\text { Basic chemicals, paints, soaps, } \\
\text { petroleum products (including } \\
\text { combinatorial chemistry) }\end{array}$ & 163.670 & 2.846 & $1,74 \%$ & 1.01 \\
\hline Medical equipment & 78.914 & 2.425 & $3,07 \%$ & 1.78 \\
\hline $\begin{array}{l}\text { Electronic components (including } \\
\text { micro-structural technology) }\end{array}$ & 70.764 & 1.150 & $1,63 \%$ & 0.94 \\
\hline Special machinery & 116.516 & 1.056 & $0,91 \%$ & 0.53 \\
\hline Polymers, rubber, man-made fibres & 144.394 & 1.033 & $0,72 \%$ & 0.41 \\
\hline $\begin{array}{l}\text { Textiles, wearing, leather, wood, paper, } \\
\text { domestic appliances, furniture, food }\end{array}$ & 106.315 & 1.008 & $0,95 \%$ & 0.55 \\
\hline Non-polymer materials & 101.210 & 998 & $0,99 \%$ & 0.57 \\
\hline $\begin{array}{l}\text { Computers, Office Machinery } \\
\text { (including data processing systems or } \\
\text { methods) }\end{array}$ & 140.988 & 985 & $0,70 \%$ & 0.41 \\
\hline Telecommunications & 104.286 & 680 & $0,65 \%$ & 0.38 \\
\hline Optics & 45.656 & 554 & $1,21 \%$ & 0.70 \\
\hline General machinery & 70.672 & 541 & $0,77 \%$ & 0.44 \\
\hline Electrical machinery, apparatus, energy & 70.273 & 430 & $0,61 \%$ & 0.35 \\
\hline Transport & 101.617 & 277 & $0,27 \%$ & 0.16 \\
\hline Audio-visual electronics & 40.867 & 269 & $0,66 \%$ & 0.38 \\
\hline Machine-tools & 40.651 & 181 & $0,45 \%$ & 0.26 \\
\hline Energy machinery & 53.491 & 158 & $0,30 \%$ & 0.17 \\
\hline Metal products & 43.220 & 148 & $0,34 \%$ & 0.20 \\
\hline
\end{tabular}


Table III. University patenting by country (EPO, application years 1980-2000).

\begin{tabular}{|l|c|c|c|c|}
\hline Country & Patents & $\begin{array}{c}\text { University } \\
\text { patents }\end{array}$ & \% university patents & $\begin{array}{c}\text { Relative } \\
\text { specialization in } \\
\text { university patenting }\end{array}$ \\
\hline CN & 810 & 84 & $10,37 \%$ & 6.55 \\
\hline AU & 8.349 & 605 & $7,25 \%$ & 4.57 \\
\hline CA & 12.845 & 868 & $6,76 \%$ & 4.27 \\
\hline BE & 11.332 & 553 & $4,88 \%$ & 3.08 \\
\hline IE & 1.827 & 74 & $4,05 \%$ & 2.56 \\
\hline US & 356.052 & 13.088 & $3,68 \%$ & 2.32 \\
\hline UK & 69.619 & 1813 & $2,60 \%$ & 1.64 \\
\hline ES & 5.122 & 124 & $2,42 \%$ & 1.53 \\
\hline NL & 42.792 & 427 & $1,00 \%$ & 0.63 \\
\hline KR & 5.289 & 45 & $0,85 \%$ & 0.54 \\
\hline FR & 95.175 & 455 & $0,48 \%$ & 0.30 \\
\hline CH & 45.071 & 180 & $0,40 \%$ & 0.25 \\
\hline IT & 39.118 & 101 & $0,26 \%$ & 0.16 \\
\hline AT & 12.422 & 29 & $0,23 \%$ & 0.15 \\
\hline FI & 10.457 & 18 & $0,17 \%$ & 0.11 \\
\hline DK & 7.846 & 12 & $0,15 \%$ & 0.10 \\
\hline JP & 208.677 & 272 & $0,13 \%$ & 0.07 \\
\hline DE & 242.533 & 278 & $0,11 \%$ & 0.05 \\
\hline SE & 25.401 & 22 & $0,09 \%$ & $\mathbf{0 , 7 8}$ \\
\hline $\begin{array}{l}\text { EU-15 } \\
\text { average }\end{array}$ & $\mathbf{3 7 7 4 1}$ & $\mathbf{2 6 1}$ & $\mathbf{1 , 2 4 \%}$ & \\
\hline
\end{tabular}


Table IV. Corporate citations to university patents, by technology field (EPO, application years 1980-2000; 10 year citation window).

\begin{tabular}{|l|c|c|c|c|c|}
\hline Technology & $\begin{array}{c}\text { University } \\
\text { patents }\end{array}$ & $\begin{array}{c}\text { \% } \\
\text { university } \\
\text { patents } \\
\text { cited by } \\
\text { company } \\
\text { patents }\end{array}$ & $\begin{array}{c}\text { Impact of } \\
\text { cited } \\
\text { university } \\
\text { patents }\end{array}$ & $\begin{array}{c}\text { \% cited } \\
\text { company } \\
\text { patents }\end{array}$ & $\begin{array}{c}\text { Impact of } \\
\text { cited } \\
\text { company } \\
\text { patents }\end{array}$ \\
\hline $\begin{array}{l}\text { Pharmaceuticals (and } \\
\text { Cosmetics) }\end{array}$ & 11.191 & $13,14 \%$ & 6,08 & $53 \%$ & 5,85 \\
\hline Measurement, control & 4.137 & $17,02 \%$ & 4,97 & $45 \%$ & 3,50 \\
\hline $\begin{array}{l}\text { Basic chemicals, paints, } \\
\text { soaps, petroleum products } \\
\text { (including combinatorial } \\
\text { chemistry) }\end{array}$ & 2.846 & $17,50 \%$ & 5,55 & $44 \%$ & 4,37 \\
\hline Medical equipment & 2.425 & $19,38 \%$ & 5,68 & $41 \%$ & 6,91 \\
\hline $\begin{array}{l}\text { Electronic components } \\
\text { (including micro-structural } \\
\text { technology) }\end{array}$ & 1.150 & $25,30 \%$ & 4,76 & $51 \%$ & 4,78 \\
\hline Special machinery & 1.056 & $14,30 \%$ & 4,31 & $43 \%$ & 3,67 \\
\hline $\begin{array}{l}\text { Polymers, rubber, man- } \\
\text { made fibres }\end{array}$ & 1.033 & $19,94 \%$ & 6,07 & $47 \%$ & 3,91 \\
\hline $\begin{array}{l}\text { Textiles, wearing, leather, } \\
\text { wood, paper, domestic } \\
\text { appliances, furniture, food }\end{array}$ & 1.008 & $16,37 \%$ & 5,84 & $49 \%$ & 5,40 \\
\hline Non-polymer materials & 998 & $24,25 \%$ & 4,06 & $48 \%$ & 4,00 \\
\hline $\begin{array}{l}\text { Computers, Office } \\
\text { Machinery (including data } \\
\text { processing systems or } \\
\text { methods) }\end{array}$ & 985 & $20,41 \%$ & 5,60 & $47 \%$ & 5,56 \\
\hline Telecommunications & 680 & $22,94 \%$ & 5,39 & $48 \%$ & 4,35 \\
\hline Optics & 554 & $25,27 \%$ & 5,20 & $42 \%$ & 5,55 \\
\hline General machinery & 541 & $22,55 \%$ & 4,06 & $44 \%$ & 3,44 \\
\hline $\begin{array}{l}\text { Electrical machinery, } \\
\text { apparatus, energy }\end{array}$ & 430 & $25,12 \%$ & 5,37 & $54 \%$ & 4,88 \\
\hline Transport & 277 & $25,63 \%$ & 2,98 & $45 \%$ & 4,52 \\
\hline Audio-visual electronics & 269 & $20,45 \%$ & 5,09 & $44 \%$ & 3,78 \\
\hline Machine-tools & 181 & $19,89 \%$ & 4,50 & $53 \%$ & 5,59 \\
\hline Energy machinery & 158 & $20,25 \%$ & 3,46 & $42 \%$ & 3,18 \\
\hline Metal products & 148 & $13,51 \%$ & 4,15 & $53 \%$ & 5,18 \\
\hline
\end{tabular}


Table V. Corporate citations to university patents, by country (EPO, application years 19902009; 10 year backward citation window).

\begin{tabular}{|l|c|c|c|c|c|c|}
\hline Country & $\begin{array}{c}\text { University } \\
\text { patents }\end{array}$ & $\begin{array}{c}\text { Country } \\
\text { share in all } \\
\text { corporate } \\
\text { citations } \\
\text { received by } \\
\text { university } \\
\text { patents }\end{array}$ & $\begin{array}{c}\text { \% university } \\
\text { owned patents } \\
\text { that are cited by } \\
\text { company patents }\end{array}$ & $\begin{array}{c}\text { Impact of } \\
\text { cited } \\
\text { university } \\
\text { owned } \\
\text { patents }\end{array}$ & $\begin{array}{c}\text { \% cited } \\
\text { company } \\
\text { owned } \\
\text { patents }\end{array}$ & $\begin{array}{c}\text { Impact } \\
\text { of cited } \\
\text { company } \\
\text { owned } \\
\text { patents }\end{array}$ \\
\hline US & 13.088 & 66.8 & $14 \%$ & 6,03 & $40 \%$ & 5,25 \\
\hline UK & 1.813 & 6.5 & $15 \%$ & 3,96 & $41 \%$ & 4,99 \\
\hline CA & 868 & 3.1 & $14 \%$ & 4,34 & $35 \%$ & 5,12 \\
\hline AU & 605 & 1.2 & $9 \%$ & 3,90 & $14 \%$ & 4,09 \\
\hline BE & 553 & 6.2 & $36 \%$ & 5,17 & $48 \%$ & 4,99 \\
\hline FR & 455 & 2.3 & $28 \%$ & 3,03 & $46 \%$ & 3,81 \\
\hline NL & 427 & 3.0 & $28 \%$ & 4,26 & $46 \%$ & 4,90 \\
\hline DE & 278 & 1.4 & $22 \%$ & 3,89 & $43 \%$ & 3,60 \\
\hline JP & 272 & 3.8 & $49 \%$ & 4,77 & $67 \%$ & 5,33 \\
\hline CH & 180 & 1.1 & $23 \%$ & 4,29 & $49 \%$ & 4,39 \\
\hline ES & 124 & 0.9 & $40 \%$ & 2,98 & $48 \%$ & 3,69 \\
\hline IT & 101 & 0.5 & $21 \%$ & 3,90 & $53 \%$ & 3,69 \\
\hline EU-15 & $\mathbf{4 0 6 2}$ & $\mathbf{2 2 . 8}$ & $\mathbf{2 7 , 8 \%}$ & 3,74 & $38 \%$ & $\mathbf{4 , 3 9}$ \\
(avg) & & & & & & \\
\hline
\end{tabular}

Table VI. A European paradox? (EPO, application years 1980-2000)

\begin{tabular}{|l|c|c|c|}
\hline & US & EU-15 & JP \\
\hline Share in university patenting & $68 \%$ & $21 \%$ & $1.4 \%$ \\
\hline Share in corporate citations received by university patents & $67 \%$ & $23 \%$ & $3.8 \%$ \\
\hline Citation Intensity Index* & 0.98 & 1.08 & 2.67 \\
\hline \% university patents cited & $14 \%$ & $28 \%$ & $49 \%$ \\
\hline Impact of cited university patents & 6.03 & 3.74 & 4.77 \\
\hline
\end{tabular}

*Citation Intensity Index measures a country's share in corporate citations received by university patents, relative to its share in university patenting. A value larger than 1 indicates that the country receives a higher number of citations per university patent than the world average. 
Table VII. Corporate use of university technology, by technology field (EPO, application years 1990-2009; 10 year backward citation window).

\begin{tabular}{|l|l|c|c|c|}
\hline & Citing technology & $\begin{array}{c}\text { \# comp } \\
\text { patents citing } \\
\text { univ patent }\end{array}$ & $\begin{array}{c}\text { \# comp } \\
\text { patents citing } \\
\text { any patent }\end{array}$ & $\begin{array}{c}\text { \% comp } \\
\text { patents citing } \\
\text { univ patent }\end{array}$ \\
\hline 12 & Pharmaceuticals (and Cosmetics) & 27453 & 152955 & $17.95 \%$ \\
\hline 6 & Measurement, control & 12631 & 105745 & $11.94 \%$ \\
\hline 7 & Medical equipment & 11344 & 96631 & $11.74 \%$ \\
\hline 2 & $\begin{array}{l}\text { Electronic components (including } \\
\text { micro-structural technology) }\end{array}$ & 5383 & 78951 & $6.82 \%$ \\
\hline 9 & $\begin{array}{l}\text { Basic chemicals, paints, soaps, } \\
\text { petroleum products (including } \\
\text { combinatorial chemistry) }\end{array}$ & 8401 & 142242 & $5.91 \%$ \\
\hline 8 & Optics & 2795 & 50634 & $5.52 \%$ \\
\hline 11 & Non-polymer materials & 3423 & 91022 & $3.76 \%$ \\
\hline 3 & Telecommunications & 5163 & 153687 & $3.36 \%$ \\
\hline 19 & $\begin{array}{l}\text { Textiles, wearing, leather, wood, } \\
\text { paper, domestic appliances, furniture, } \\
\text { food }\end{array}$ & 3405 & 105539 & $3.23 \%$ \\
\hline 4 & Audio-visual electronics & 1740 & 55399 & $3.14 \%$ \\
\hline 5 & $\begin{array}{l}\text { Computers, Office Machinery } \\
\text { (including data processing systems or } \\
\text { methods) }\end{array}$ & 5762 & 184349 & $3.13 \%$ \\
\hline 14 & General machinery & 1985 & 65312 & $3.04 \%$ \\
\hline 10 & Polymers, rubber, man-made fibres & 4010 & 135864 & $2.95 \%$ \\
\hline 1 & $\begin{array}{l}\text { Electrical machinery, apparatus, } \\
\text { energy }\end{array}$ & 2310 & 79004 & $2.92 \%$ \\
\hline 16 & Special machinery & 2773 & 102068 & $2.72 \%$ \\
\hline 15 & Machine-tools & 783 & 36844 & $2.13 \%$ \\
\hline 13 & Energy machinery & 58791 & $1.33 \%$ \\
\hline 18 & Metal products & 39450 & $1.29 \%$ \\
\hline 17 & Transport & 1501 & $1.22 \%$ \\
\hline
\end{tabular}


Table VIII. Corporate use of university technology, by country (EPO, application years 19902009; 10 year backward citation windox).

\begin{tabular}{|l|c|c|c|}
\hline $\begin{array}{l}\text { Citing } \\
\text { country* }\end{array}$ & $\begin{array}{c}\text { \# comp patents } \\
\text { citing univ patent }\end{array}$ & $\begin{array}{c}\text { \# company patents } \\
\text { citing any patent }\end{array}$ & $\begin{array}{c}\text { \% company patents that cite } \\
\text { university patent(s) }\end{array}$ \\
\hline US & 30129 & 390422 & $7.72 \%$ \\
\hline JP & 8424 & 271122 & $3.11 \%$ \\
\hline DE & 8397 & 250344 & $3.35 \%$ \\
\hline UK & 3873 & 54745 & $7.07 \%$ \\
\hline FR & 2985 & 88282 & $3.38 \%$ \\
\hline NL & 2933 & 51351 & $5.71 \%$ \\
\hline CH & 2539 & 47212 & $5.38 \%$ \\
\hline EU-15 avg & 1622 & 38930 & $5.29 \%$ \\
\hline SE & 1427 & 27260 & $5.23 \%$ \\
\hline CA & 1395 & 15506 & $9.00 \%$ \\
\hline IT & 1132 & 39510 & $2.87 \%$ \\
\hline KR & 1005 & 21819 & $4.61 \%$ \\
\hline AU & 963 & 7474 & $12.88 \%$ \\
\hline DK & 814 & 9836 & $8.28 \%$ \\
\hline BE & 722 & 12421 & $5.81 \%$ \\
\hline FI & 626 & 15927 & $3.93 \%$ \\
\hline AT & 599 & 11649 & $5.14 \%$ \\
\hline CN & 508 & 4301 & $11.81 \%$ \\
\hline NO & 324 & 3754 & $8.63 \%$ \\
\hline ES & 302 & 5811 & $5.20 \%$ \\
\hline IE & 201 & 2659 & $7.56 \%$ \\
\hline
\end{tabular}

* countries are only included if they have more than 200 company patents that cite university patents. For all countries, see Appendix table VI.

Table IX. A European paradox continued?

\begin{tabular}{|l|c|c|c|}
\hline & US & EU-15 & JP \\
\hline Share of corporate patents which cite university patents & $5.4 \%$ & $3.9 \%$ & $2.9 \%$ \\
\hline Citations to university patent per corporate patent citing & 1.28 & 1.19 & 1.16 \\
\hline
\end{tabular}

Note: EU15 and Japan are significantly lower than others $(<1 \%)$ on both dimensions. 
Table X. Cross-country links between corporate citing patents and university cited patents (EPO, application years 1980-2000; 10 year backward citation window).

\begin{tabular}{|c|c|c|c|c|c|c|c|c|c|c|c|c|c|c|c|c|c|}
\hline & & \multicolumn{16}{|c|}{ CITED COUNTRIES } \\
\hline & & AT & $\mathrm{AU}$ & $\mathrm{BE}$ & CA & $\mathrm{CH}$ & $\mathrm{CN}$ & $\mathrm{DE}$ & ES & FR & IE & IT & JP & KR & NL & UK & US \\
\hline \multirow{16}{*}{ 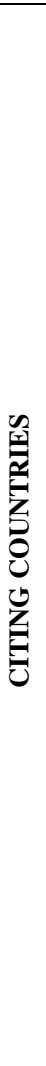 } & AT & 3.77 & 0.00 & 1.76 & 2.62 & 1.27 & 0.00 & 0.00 & 2.94 & 1.17 & 0.00 & 0.00 & 0.72 & 0.00 & 1.84 & 1.88 & 0.78 \\
\hline & $\mathrm{AU}$ & 0.00 & 7.22 & 0.42 & 4.15 & 0.00 & 0.00 & 0.00 & 0.93 & 1.11 & 0.00 & 0.00 & 1.84 & 37.83 & 0.29 & 1.73 & 0.70 \\
\hline & $\mathrm{BE}$ & 0.00 & 0.44 & 4.99 & 0.17 & 5.35 & 0.00 & 0.00 & 1.69 & 0.90 & 7.66 & 0.00 & 2.51 & 0.00 & 0.71 & 0.80 & 0.51 \\
\hline & CA & 0.00 & 0.21 & 0.77 & 6.72 & 1.16 & 2.88 & 0.52 & 0.27 & 0.43 & 1.31 & 0.00 & 0.33 & 0.00 & 0.67 & 1.69 & 0.79 \\
\hline & $\mathrm{CH}$ & 0.64 & 0.19 & 0.63 & 1.10 & 4.27 & 4.51 & 0.64 & 1.74 & 1.77 & 0.72 & 0.00 & 0.73 & 0.00 & 1.78 & 2.22 & 0.78 \\
\hline & $\mathrm{CN}$ & 0.00 & 6.39 & 2.47 & 0.00 & 0.00 & 17.66 & 0.00 & 0.00 & 3.28 & 0.00 & 0.00 & 2.03 & 0.00 & 0.00 & 2.35 & 0.46 \\
\hline & $\overline{\mathrm{DE}}$ & 4.62 & 1.34 & 1.22 & 1.01 & 2.08 & 1.26 & 2.69 & 1.04 & 1.35 & 1.21 & 3.51 & 0.82 & 2.80 & 0.84 & 1.11 & 0.86 \\
\hline & ES & 0.00 & 1.60 & 0.62 & 1.22 & 0.00 & 2.21 & 0.00 & 16.51 & 4.10 & 0.00 & 0.00 & 3.05 & 0.00 & 1.29 & 0.29 & 0.69 \\
\hline & FR & 1.06 & 1.81 & 1.05 & 0.98 & 0.47 & 1.33 & 0.98 & 1.79 & 5.58 & 2.27 & 1.81 & 0.92 & 0.00 & 0.30 & 0.63 & 0.87 \\
\hline & IE & 0.00 & 0.00 & 2.06 & 0.82 & 0.00 & 0.00 & 1.78 & 0.00 & 0.00 & 31.99 & 0.00 & 0.00 & 0.00 & 0.00 & 0.00 & 0.77 \\
\hline & IT & 0.00 & 1.25 & 1.37 & 0.80 & 0.93 & 0.00 & 0.00 & 3.78 & 0.64 & 0.52 & 2.03 & 1.73 & 0.00 & 0.84 & 1.00 & 0.95 \\
\hline & JP & 0.15 & 0.68 & 0.82 & 0.70 & 0.25 & 1.38 & 1.06 & 1.29 & 0.84 & 0.28 & 0.33 & 2.63 & 0.95 & 0.62 & 1.17 & 0.98 \\
\hline & KR & 0.00 & 0.00 & 2.13 & 0.00 & 0.94 & 1.17 & 0.00 & 1.10 & 0.00 & 0.00 & 0.00 & 1.89 & 35.51 & 3.08 & 1.87 & 0.76 \\
\hline & NL & 1.39 & 0.67 & 1.17 & 0.72 & 1.19 & 0.74 & 4.26 & 0.35 & 0.82 & 3.02 & 3.25 & 1.28 & 0.88 & 4.65 & 0.96 & 0.74 \\
\hline & UK & 0.00 & 0.84 & 0.94 & 0.81 & 1.12 & 0.70 & 1.05 & 0.33 & 0.73 & 0.63 & 0.82 & 0.62 & 0.00 & 1.12 & 1.87 & 0.97 \\
\hline & US & 0.68 & 0.92 & 0.87 & 0.80 & 0.75 & 0.61 & 0.57 & 0.82 & 0.59 & 0.62 & 0.55 & 0.71 & 0.20 & 0.83 & 0.78 & 1.12 \\
\hline
\end{tabular}


APPENDIX Table A.I. ANCOVA: country and field effects on the amount of patent activity undertaken by universities (EPO, application years 1980-2000).

\begin{tabular}{|l|c|c|c|c|c|}
\hline & \multicolumn{5}{|c|}{ DEPVAR = number of university patents } \\
\hline & Type III Sum of Squares & Df & Mean Square & F & Sig. \\
\hline Corrected Model & $4.188 E 6$ & 376 & 11137.177 & 11.576 & .000 \\
\hline Intercept & 173560.294 & 1 & 173560.294 & 180.392 & .000 \\
\hline Application year & 173784.455 & 1 & 173784.455 & 180.625 & .000 \\
\hline Technology field & 45827.305 & 18 & 2545.961 & 2.646 & .000 \\
\hline Country & 876069.267 & 29 & 30209.285 & 31.398 & .000 \\
\hline Technology field * country & 2686274.243 & 328 & 8189.860 & 8.512 & .000 \\
\hline Error & 2302372.792 & 2393 & 962.128 & 962.128 & \\
\hline Total & 6819862.000 & 2770 & & & \\
\hline Corrected Total & 6489951.206 & 2769 & & & \\
\hline & \multicolumn{7}{|c|}{ R Squared =,645 (Adjusted R Squared = ,589) } \\
\hline
\end{tabular}


APPENDIX Table A.II. University patenting by country (EPO, application years 1980-2000).

\begin{tabular}{|c|c|c|c|c|}
\hline Country & Patents & University patents & $\%$ university patents & $\begin{array}{l}\text { Relative specialization in } \\
\text { university patenting }\end{array}$ \\
\hline US & 356052 & 13088 & $3,68 \%$ & 2.32 \\
\hline $\mathrm{DE}$ & 242533 & 278 & $0,11 \%$ & 0.07 \\
\hline JP & 208677 & 272 & $0,13 \%$ & 0.08 \\
\hline FR & 95175 & 455 & $0,48 \%$ & 0.30 \\
\hline UK & 69619 & 1813 & $2,60 \%$ & 1.64 \\
\hline $\mathrm{CH}$ & 45071 & 180 & $0,40 \%$ & 0.25 \\
\hline NL & 42792 & 427 & $1,00 \%$ & 0.63 \\
\hline IT & 39118 & 101 & $0,26 \%$ & 0.16 \\
\hline SE & 25401 & 22 & $0,09 \%$ & 0.05 \\
\hline CA & 12845 & 868 & $6,76 \%$ & 4.27 \\
\hline AT & 12422 & 29 & $0,23 \%$ & 0.15 \\
\hline $\mathrm{BE}$ & 11332 & 553 & $4,88 \%$ & 3.08 \\
\hline FI & 10457 & 18 & $0,17 \%$ & 0.11 \\
\hline $\mathrm{AU}$ & 8349 & 605 & $7,25 \%$ & 4.57 \\
\hline DK & 7846 & 12 & $0,15 \%$ & 0.10 \\
\hline KR & 5289 & 45 & $0,85 \%$ & 0.54 \\
\hline ES & 5122 & 124 & $2,42 \%$ & 1.53 \\
\hline $\mathrm{NO}$ & 3639 & 4 & $0,11 \%$ & 0.07 \\
\hline TW & 2021 & 2 & $0,10 \%$ & 0.06 \\
\hline $\mathrm{IE}$ & 1827 & 74 & $4,05 \%$ & 2.56 \\
\hline $\mathrm{LU}$ & 1753 & 0 & $0,00 \%$ & 0 \\
\hline $\mathrm{HU}$ & 1615 & 28 & $1,73 \%$ & 1.09 \\
\hline $\mathrm{NZ}$ & 1064 & 29 & $2,73 \%$ & 1.72 \\
\hline $\mathrm{CN}$ & 810 & 84 & $10,37 \%$ & 6.55 \\
\hline GR & 446 & 3 & $0,67 \%$ & 0.42 \\
\hline $\mathrm{PL}$ & 352 & 66 & $18,75 \%$ & 11.84 \\
\hline $\mathrm{CZ}$ & 287 & 3 & $1,05 \%$ & 0.66 \\
\hline
\end{tabular}




\begin{tabular}{|l|c|c|c|c|}
\hline PT & 266 & 4 & $1,50 \%$ & 0.95 \\
\hline MX & 197 & 13 & $6,60 \%$ & 4.17 \\
\hline TR & 115 & 1 & $0,87 \%$ & 0.55 \\
\hline IS & 89 & 0 & $0,00 \%$ & 0 \\
\hline SK & 71 & 7 & $9,86 \%$ & 6.22 \\
\hline EU-15 average & $\mathbf{3 7 7 4 1}$ & $\mathbf{2 6 1}$ & $\mathbf{1 , 2 4 \%}$ & $\mathbf{0 , 7 8}$ \\
\hline
\end{tabular}

APPENDIX Table A.III. ANCOVA: country and field effects on the share and impact of cited university patents (EPO, application years 1980-2000; 10 year citation window).

\begin{tabular}{|c|c|c|c|c|c|c|c|c|c|c|}
\hline & \multicolumn{5}{|c|}{$\begin{array}{c}\text { DEPVAR = \% university patents cited by company } \\
\text { patents }\end{array}$} & \multicolumn{5}{|c|}{ DEPVAR = impact of cited university patents } \\
\hline & $\begin{array}{c}\text { Type III Sum of } \\
\text { Squares }\end{array}$ & Df & $\begin{array}{c}\text { Mean } \\
\text { Square }\end{array}$ & $\mathbf{F}$ & Sig. & $\begin{array}{c}\text { Type III Sum } \\
\text { of Squares }\end{array}$ & df & $\begin{array}{c}\text { Mean } \\
\text { Square }\end{array}$ & $\mathbf{F}$ & Sig. \\
\hline Corrected Model & $165,904^{\mathrm{a}}$ & 376 & ,441 & 4,203 &, 000 & $7779,860^{\mathrm{a}}$ & 285 & 27,298 & 1,201 & 020 \\
\hline Intercept & 51,357 & 1 & 51,357 & 489,201 & 000 & 136,207 & 1 & 136,207 & 5,993 & ,014 \\
\hline Application year & 50,749 & 1 & 50,749 & 483,406 &, 000 & 125,243 & 1 & 125,243 & 5,510 & 019 \\
\hline Technology field & 3,102 & 18 &, 172 & \begin{tabular}{|l|}
1,642 \\
\end{tabular} &, 043 & 485,542 & 18 & 26,975 & 1,187 & ,264 \\
\hline Country & 50,208 & 29 & 1,731 & 16,492 & 000 & 2091,142 & 24 & 87,131 & 3,834 & 000 \\
\hline $\begin{array}{l}\text { Technology field * } \\
\text { country }\end{array}$ & 53,652 & 328 & ,164 & 1,558 & ,000 & 4964,598 & 242 & 20,515 & ,903 & ,842 \\
\hline Error & 251,221 & 2393 & & & & 31046,608 & 1366 & 22,728 & & \\
\hline Total & 749,281 & 2770 & & & & 79309,647 & 1652 & & & \\
\hline \multirow[t]{2}{*}{ Corrected Total } & 417,125 & 2769 & & & & 38826,469 & 1651 & & & \\
\hline & \multicolumn{5}{|c|}{ R Squared $=, 398$ (Adjusted R Squared $=, 303)$} & \multicolumn{5}{|c|}{ R Squared $=, 200$ (Adjusted R Squared $=, 034)$} \\
\hline
\end{tabular}


APPENDIX Table A.IV. ANCOVA: country and field effects in corporate absorption of university technology (EPO, application years 1990-2009; 10 year backward citation window).

\begin{tabular}{|c|c|c|c|c|c|c|c|c|c|c|}
\hline & \multicolumn{5}{|c|}{$\begin{aligned} \text { DEPVAR = } & \text { share of corporate patents citing (1 or } \\
& \text { more) university patent(s) }\end{aligned}$} & \multicolumn{5}{|c|}{$\begin{array}{c}\text { DEPVAR = citation intensity (avg \# } \\
\text { backward citations) of corporate patents } \\
\text { citing university patents }\end{array}$} \\
\hline & $\begin{array}{c}\text { Type III Sum of } \\
\text { Squares }\end{array}$ & Df & $\begin{array}{c}\text { Mean } \\
\text { Square }\end{array}$ & $\mathbf{F}$ & Sig. & $\begin{array}{l}\text { Type III } \\
\text { Sum of } \\
\text { Squares } \\
\end{array}$ & df & $\begin{array}{c}\text { Mean } \\
\text { Square }\end{array}$ & $\mathbf{F}$ & Sig. \\
\hline Corrected Model & $30,311^{\mathrm{a}}$ & 601 &, 050 & 6,913 & 000 & $170,725^{\mathrm{a}}$ & 500 & ,341 & 2,595 &, 000 \\
\hline Intercept & ,826 & 1 & ,826 & 113,189 & 000 & 7,419 & 1 & 7,419 & 56,395 &, 000 \\
\hline Application year & 3,659 & 31 & ,118 & 16,179 & ,000 & 22,372 & 31 & ,722 & 5,485 & ,000 \\
\hline Technology field & 12,204 & 18 & ,678 & 92,934 & 000 & 21,819 & 18 & 1,212 & 9,214 & , 000 \\
\hline Country & ,851 & 1 & ,851 & 116,640 &, 000 & 8,676 & 1 & 8,676 & 65,945 &, 000 \\
\hline $\begin{array}{l}\text { Technology field * } \\
\text { country }\end{array}$ & 11,215 & 551 & ,020 & 2,790 & ,000 & 92,677 & 450 & ,206 & 1,565 & ,000 \\
\hline Error & 66,132 & 9065 & ,007 & & & 655,423 & 4982 & ,132 & & \\
\hline Total & 118,318 & 9667 & & & & 8987,450 & 5483 & & & \\
\hline \multirow[t]{2}{*}{ Corrected Total } & 96,442 & 9666 & & & & 826,149 & 5482 & & & \\
\hline & \multicolumn{5}{|c|}{${ }^{\mathrm{a}} \mathrm{R}$ Squared $=, 314$ (Adjusted R Squared $=, 269$ ) } & \multicolumn{5}{|c|}{${ }^{\mathrm{a}} \mathrm{R}$ Squared $=, 207$ (Adjusted R Squared $=, 127$ ) } \\
\hline
\end{tabular}


APPENDIX Table A.V. Corporate use of university technology, by country (EPO, application years 1990-2009; 10 year backward citation window).

\begin{tabular}{|l|c|c|c|}
\hline $\begin{array}{l}\text { Citing } \\
\text { country* }\end{array}$ & $\begin{array}{c}\text { \# comp patents } \\
\text { citing univ } \\
\text { patent }\end{array}$ & $\begin{array}{c}\text { \# company } \\
\text { patents citing } \\
\text { any patent }\end{array}$ & $\begin{array}{c}\text { \% company } \\
\text { patents that } \\
\text { cite university } \\
\text { patent(s) }\end{array}$ \\
\hline US & 30129 & 390422 & $7.72 \%$ \\
\hline JP & 8424 & 271122 & $3.11 \%$ \\
\hline DE & 8397 & 250344 & $3.35 \%$ \\
\hline UK & 3873 & 54745 & $7.07 \%$ \\
\hline FR & 2985 & 88282 & $3.38 \%$ \\
\hline NL & 2933 & 51351 & $5.71 \%$ \\
\hline CH & 2539 & 47212 & $5.38 \%$ \\
\hline EU-15 avg & 1622 & 38930 & $5.29 \%$ \\
\hline SE & 1427 & 27260 & $5.23 \%$ \\
\hline CA & 1395 & 15506 & $9.00 \%$ \\
\hline IT & 1132 & 39510 & $2.87 \%$ \\
\hline KR & 1005 & 21819 & $4.61 \%$ \\
\hline AU & 963 & 7474 & $12.88 \%$ \\
\hline DK & 814 & 9836 & $8.28 \%$ \\
\hline BE & 722 & 12421 & $5.81 \%$ \\
\hline FI & 626 & 15927 & $3.93 \%$ \\
\hline AT & 599 & 11649 & $5.14 \%$ \\
\hline CN & 508 & 4301 & $11.81 \%$ \\
\hline NO & 324 & 3754 & $8.63 \%$ \\
\hline ES & 302 & 5811 & $5.20 \%$ \\
\hline IE & 201 & 2659 & $7.56 \%$ \\
\hline NZ & 138 & 1243 & $11.10 \%$ \\
\hline TW & 122 & 3207 & $3.80 \%$ \\
\hline & & & \\
\hline
\end{tabular}




\begin{tabular}{|l|c|c|c|}
\hline LU & 95 & 1967 & $4.83 \%$ \\
\hline HU & 41 & 574 & $7.14 \%$ \\
\hline IS & 31 & 222 & $13.96 \%$ \\
\hline PL & 20 & 275 & $7.27 \%$ \\
\hline CZ & 18 & 420 & $4.29 \%$ \\
\hline PT & 17 & 329 & $5.17 \%$ \\
\hline GR & 11 & 190 & $5.79 \%$ \\
\hline MX & 10 & 141 & $7.09 \%$ \\
\hline SK & 4 & 69 & $5.80 \%$ \\
\hline TR & 4 & 487 & $0.82 \%$ \\
\hline
\end{tabular}


APPENDIX Table A.VI. Row proportions of cited countries per citing country (EPO, application years 1980-2000; 10 year citation window).

\begin{tabular}{|c|c|c|c|c|c|c|c|c|c|c|c|c|c|c|c|c|c|c|c|c|c|c|c|c|c|}
\hline & & \multicolumn{24}{|c|}{ CITED COUNTRIES } \\
\hline & & AT & $\mathrm{AU}$ & $\mathrm{BE}$ & $\mathrm{CA}$ & $\mathrm{CH}$ & $\mathrm{CN}$ & $\overline{\mathrm{DE}}$ & ES & FR & UK & $\mathrm{HU}$ & $\mathrm{IE}$ & IT & $\mathrm{JP}$ & KR & MX & NL & $\mathrm{NO}$ & $\mathrm{NZ}$ & PL & PT & SE & SK & US \\
\hline \multirow{21}{*}{ 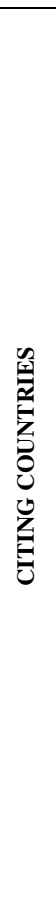 } & AT & $1 \%$ & $0 \%$ & $11 \%$ & $8 \%$ & $1 \%$ & $0 \%$ & $0 \%$ & $3 \%$ & $3 \%$ & $12 \%$ & $0 \%$ & $0 \%$ & $0 \%$ & $3 \%$ & $0 \%$ & $0 \%$ & $5 \%$ & $0 \%$ & $0 \%$ & $0 \%$ & $0 \%$ & $0 \%$ & $0 \%$ & $52 \%$ \\
\hline & $\mathrm{AU}$ & $0 \%$ & $9 \%$ & $3 \%$ & $13 \%$ & $0 \%$ & $0 \%$ & $0 \%$ & $1 \%$ & $3 \%$ & $11 \%$ & $0 \%$ & $0 \%$ & $0 \%$ & \begin{tabular}{|l|}
$7 \%$ \\
\end{tabular} & $4 \%$ & $1 \%$ & $1 \%$ & $0 \%$ & $0 \%$ & $0 \%$ & $0 \%$ & $0 \%$ & $0 \%$ & $47 \%$ \\
\hline & $\mathrm{BE}$ & $0 \%$ & $1 \%$ & $31 \%$ & $1 \%$ & $6 \%$ & $0 \%$ & $0 \%$ & $2 \%$ & $2 \%$ & $5 \%$ & $0 \%$ & $7 \%$ & $0 \%$ & \begin{tabular}{|l|}
$9 \%$ \\
\end{tabular} & $0 \%$ & $0 \%$ & $2 \%$ & $0 \%$ & $0 \%$ & $0 \%$ & $0 \%$ & $0 \%$ & $0 \%$ & $34 \%$ \\
\hline & CA & $0 \%$ & $0 \%$ & $5 \%$ & $21 \%$ & $1 \%$ & $3 \%$ & $1 \%$ & $0 \%$ & $1 \%$ & $11 \%$ & $0 \%$ & $1 \%$ & $0 \%$ & \begin{tabular}{|l|}
$1 \%$ \\
\end{tabular} & $0 \%$ & $0 \%$ & $2 \%$ & $0 \%$ & $0 \%$ & $0 \%$ & $0 \%$ & $0 \%$ & $0 \%$ & $53 \%$ \\
\hline & $\mathrm{CH}$ & $0 \%$ & $0 \%$ & $4 \%$ & $3 \%$ & $5 \%$ & $4 \%$ & $1 \%$ & $2 \%$ & $4 \%$ & $15 \%$ & $0 \%$ & $1 \%$ & $0^{\circ}$ & $3 \%$ & $0 \%$ & $0 \%$ & $5 \%$ & $0 \%$ & $0 \%$ & $1 \%$ & $0 \%$ & $0 \%$ & $0 \%$ & $52 \%$ \\
\hline & CN & $0 \%$ & $8 \%$ & $15 \%$ & $0 \%$ & $0 \%$ & $15 \%$ & $0 \%$ & $0 \%$ & $8 \%$ & $15 \%$ & $0 \%$ & $0 \%$ & $0 \%$ & \begin{tabular}{|l|}
$8 \%$ \\
\end{tabular} & $0 \%$ & $0 \%$ & $0 \%$ & $0 \%$ & $0 \%$ & $0 \%$ & $0 \%$ & $0 \%$ & $0 \%$ & $31 \%$ \\
\hline & $\mathrm{DE}$ & $2 \%$ & $2 \%$ & $8 \%$ & $3 \%$ & $2 \%$ & $1 \%$ & $4 \%$ & $1 \%$ & $3 \%$ & $7 \%$ & $0 \%$ & $1 \%$ & $2 \%$ & $3 \%$ & $0 \%$ & $0 \%$ & $3 \%$ & $0 \%$ & $0 \%$ & $0 \%$ & $0 \%$ & $0 \%$ & $0 \%$ & $57 \%$ \\
\hline & DK & $1 \%$ & $3 \%$ & $11 \%$ & $2 \%$ & $0 \%$ & $1 \%$ & $1 \%$ & $0 \%$ & $2 \%$ & $5 \%$ & $0 \%$ & $1 \%$ & $0 \%$ & $3 \%$ & $0 \%$ & $0 \%$ & $2 \%$ & $0 \%$ & $0 \%$ & $0 \%$ & $0 \%$ & $2 \%$ & $0 \%$ & $64 \%$ \\
\hline & ES & $0 \%$ & $2 \%$ & \begin{tabular}{|l|}
$4 \%$ \\
\end{tabular} & $4 \%$ & $0 \%$ & $2 \%$ & $0 \%$ & $15 \%$ & $10 \%$ & $2 \%$ & $0 \%$ & $0 \%$ & $0 \%$ & $12 \%$ & $0 \%$ & $0 \%$ & $4 \%$ & $0 \%$ & $0 \%$ & $0 \%$ & $0 \%$ & $0 \%$ & $0 \%$ & $46 \%$ \\
\hline & FI & $0 \%$ & $4 \%$ & $11 \%$ & $7 \%$ & $0 \%$ & $7 \%$ & $0 \%$ & $0 \%$ & $2 \%$ & $9 \%$ & $0 \%$ & $3 \%$ & $0 \%$ & \begin{tabular}{|l|}
$2 \%$ \\
\end{tabular} & $0 \%$ & $0 \%$ & $10 \%$ & $0 \%$ & $0 \%$ & $0 \%$ & $0 \%$ & $0 \%$ & $0 \%$ & $44 \%$ \\
\hline & FR & $0 \%$ & $2 \%$ & $7 \%$ & $3 \%$ & $1 \%$ & $1 \%$ & $1 \%$ & $2 \%$ & $13 \%$ & $4 \%$ & $0 \%$ & $2 \%$ & $1 \%$ & \begin{tabular}{|l|}
$3 \%$ \\
\end{tabular} & $0 \%$ & $0 \%$ & $1 \%$ & $0 \%$ & $0 \%$ & $0 \%$ & $0 \%$ & $0 \%$ & $0 \%$ & $58 \%$ \\
\hline & UK & $1 \%$ & $1 \%$ & $6 \%$ & $3 \%$ & $1 \%$ & $1 \%$ & $2 \%$ & $0 \%$ & $2 \%$ & $12 \%$ & $0 \%$ & $1 \%$ & $0 \%$ & $2 \%$ & $0 \%$ & $0 \%$ & $3 \%$ & $0 \%$ & $0 \%$ & $1 \%$ & $0 \%$ & $0 \%$ & $0 \%$ & $65 \%$ \\
\hline & $\begin{array}{l}\text { IT } \\
\end{array}$ & $0 \%$ & $2 \%$ & \begin{tabular}{|l|}
$9 \%$ \\
\end{tabular} & $3 \%$ & $1 \%$ & $0 \%$ & $0 \%$ & $4 \%$ & $2 \%$ & $7 \%$ & $0 \%$ & $1 \%$ & $1 \%$ & $7 \%$ & $0 \%$ & $0 \%$ & $3 \%$ & $0 \%$ & $0 \%$ & $0 \%$ & $0 \%$ & $0 \%$ & $1 \%$ & $63 \%$ \\
\hline & JP & $0 \%$ & $1 \%$ & $5 \%$ & $2 \%$ & $0 \%$ & $1 \%$ & $2 \%$ & $1 \%$ & $2 \%$ & $8 \%$ & $0 \%$ & $0 \%$ & $0 \%$ & \begin{tabular}{|l|}
$10 \%$ \\
\end{tabular} & $0 \%$ & $0 \%$ & $2 \%$ & $0 \%$ & $0 \%$ & $0 \%$ & $0 \%$ & $0 \%$ & $0 \%$ & $65 \%$ \\
\hline & KR & $0 \%$ & $0 \%$ & $13 \%$ & $0 \%$ & $1 \%$ & $1 \%$ & $0 \%$ & $1 \%$ & $0 \%$ & $12 \%$ & $0 \%$ & $0 \%$ & $0 \%$ & \begin{tabular}{|l|}
$7 \%$ \\
\end{tabular} & $4 \%$ & $0 \%$ & $9 \%$ & $0 \%$ & $0 \%$ & $0 \%$ & $0 \%$ & $0 \%$ & $0 \%$ & $51 \%$ \\
\hline & NL & $0 \%$ & $1 \%$ & \begin{tabular}{|l|}
$7 \%$ \\
\end{tabular} & $2 \%$ & $1 \%$ & $1 \%$ & $6 \%$ & $0 \%$ & $2 \%$ & $6 \%$ & $0 \%$ & $3 \%$ & $2 \%$ & $5 \%$ & $0 \%$ & $0 \%$ & $14 \%$ & $0 \%$ & $0 \%$ & $0 \%$ & $0 \%$ & $0 \%$ & $0 \%$ & $49 \%$ \\
\hline & $\mathrm{NO}$ & $0 \%$ & $0 \%$ & \begin{tabular}{|l|}
$9 \%$ \\
\end{tabular} & $3 \%$ & $0 \%$ & $0 \%$ & $15 \%$ & $0 \%$ & $0 \%$ & $3 \%$ & $0 \%$ & $0 \%$ & $0 \%$ & \begin{tabular}{|l|}
$0 \%$ \\
\end{tabular} & $0 \%$ & $0 \%$ & $0 \%$ & $0 \%$ & $0 \%$ & $0 \%$ & $0 \%$ & $0 \%$ & $0 \%$ & $71 \%$ \\
\hline & $\mathrm{NZ}$ & $0 \%$ & $9 \%$ & \begin{tabular}{|l|}
$0 \%$ \\
\end{tabular} & $0 \%$ & $18 \%$ & $0 \%$ & $0 \%$ & $0 \%$ & $0 \%$ & $18 \%$ & $0 \%$ & $0 \%$ & $0 \%$ & \begin{tabular}{|l|}
$0 \%$ \\
\end{tabular} & $0 \%$ & $9 \%$ & $0 \%$ & $0 \%$ & $0 \%$ & $0 \%$ & $0 \%$ & $0 \%$ & $0 \%$ & $45 \%$ \\
\hline & SE & $0 \%$ & $1 \%$ & \begin{tabular}{|l|}
$6 \%$ \\
\end{tabular} & $5 \%$ & $1 \%$ & $1 \%$ & $0 \%$ & $1 \%$ & $2 \%$ & $5 \%$ & $0 \%$ & $1 \%$ & $2 \%$ & \begin{tabular}{|l|}
$3 \%$ \\
\end{tabular} & $0 \%$ & $0 \%$ & $5 \%$ & $0 \%$ & $2 \%$ & $0 \%$ & $0 \%$ & $0 \%$ & $0 \%$ & $65 \%$ \\
\hline & TW & $0 \%$ & $0 \%$ & $50 \%$ & $10 \%$ & $0 \%$ & $0 \%$ & $10 \%$ & $0 \%$ & $0 \%$ & $10 \%$ & $0 \%$ & $0 \%$ & $0 \%$ & $0 \%$ & $0 \%$ & $0 \%$ & $0 \%$ & $0 \%$ & $0 \%$ & $0 \%$ & $0 \%$ & $0 \%$ & $0 \%$ & $20 \%$ \\
\hline & US & $0 \%$ & $1 \%$ & $5 \%$ & $3 \%$ & $1 \%$ & $1 \%$ & $1 \%$ & $1 \%$ & $1 \%$ & $5 \%$ & $0 \%$ & $1 \%$ & $0 \%$ & $3 \%$ & $0 \%$ & $0 \%$ & $2 \%$ & $0 \%$ & $0 \%$ & $0 \%$ & $0 \%$ & $0 \%$ & $0 \%$ & $75 \%$ \\
\hline
\end{tabular}

